\title{
Human Long Noncoding RNA Interactome: Detection, Characterization and Function
}

\author{
Marek Kazimierczyk@, Marta K. Kasprowicz, Marta E. Kasprzyk@ and Jan Wrzesinski *๑ \\ Institute of Bioorganic Chemistry, Polish Academy of Sciences, Noskowskiego 12/14, 61-704 Poznań, Poland; \\ mkazimierczyk@man.poznan.pl (M.K.); mkasprowicz@ibch.poznan.pl (M.K.K.); \\ martha.kasprzyk@gmail.com (M.E.K.) \\ * Correspondence: wrzesinj@ibch.poznan.pl
}

Received: 3 January 2020; Accepted: 2 February 2020; Published: 4 February 2020

\begin{abstract}
The application of a new generation of sequencing techniques has revealed that most of the genome has already been transcribed. However, only a small part of the genome codes proteins. The rest of the genome "dark matter" belongs to divergent groups of non-coding RNA (ncRNA), that is not translated into proteins. There are two groups of ncRNAs, which include small and long non-coding RNAs (sncRNA and lncRNA respectively). Over the last decade, there has been an increased interest in lncRNAs and their interaction with cellular components. In this review, we presented the newest information about the human lncRNA interactome. The term IncRNA interactome refers to cellular biomolecules, such as nucleic acids, proteins, and peptides that interact with lncRNA. The lncRNA interactome was characterized in the last decade, however, understanding what role the biomolecules associated with lncRNA play and the nature of these interactions will allow us to better understand lncRNA's biological functions in the cell. We also describe a set of methods currently used for the detection of lncRNA interactome components and the analysis of their interactions. We think that such a holistic and integrated analysis of the lncRNA interactome will help to better understand its potential role in the development of organisms and cancers.
\end{abstract}

Keywords: long noncoding RNA; lncRNA; lncRNA interactome; detection lncRNA interactome; lncRNA interactome function

\section{Introduction}

It was estimated from the data obtained during the ENCODE project that $70-80 \%$ of the human genome has been transcribed [1], but that only $2 \%$ of the genome codes proteins [2]. The function of the genome "dark matter", non-coding RNAs (ncRNA), has not yet been fully recognized [3]. During the last few years, the application of RNA-seq methods has made it possible to display a divergent repertoire of ncRNAs. ncRNA is classified based on the length of the transcripts [4]. Transcripts containing over 200 nucleotides are considered to be lncRNAs and RNAs smaller than 200 nucleotides were arbitrarily classified as sncRNAs, which encompass miRNA, siRNA, piRNA and tRF [5].

Micro RNAs (miRNAs) are small RNAs made up of 21 to 23 nucleotides with well-defined biogenesis and maturation pathways [6]. They play a pivotal role in controlling gene expression $[7,8]$. siRNAs perform a similar function, although they originate from long precursors, i.e., repetitive and transposon sequences of the genome [9]. piRNAs (Piwi-interacting RNAs) are the largest group of sncRNAs and are mainly present in germ cells [10-12]. The mechanisms of piRNA biogenesis involve several Piwi proteins, resulting in 30-35 nt single-stranded RNAs. This guards germ cells against transposon activity [12]. Moreover, abnormal expression of Piwi proteins and piRNAs results in the lack of fertility in males [10-12]. The newly discovered group of snRNA, tRF RNAs, are essentially 
tRNA fragments [13]. The production of some tRFs under stress conditions is involved in translation repression $[13,14]$.

Much less is known about the biology of lncRNA, which constitutes a significant part of the non-coding genome $[4,15]$. Recent results achieved using high-through sequencing technologies indicated a high level of diversity in lncRNA classes [16]. They are very heterogeneous in terms of size as lncRNAs number from several hundred to several thousand nucleotides. Furthermore, lncRNA transcripts are derived from different parts of the genome, and lncRNAs are localized in the nucleus or in the cytoplasm. A good example of this is the well-defined nuclear Xist [17] and cytoplasmic Uchl1 IncRNAs [18].

Usually, IncRNAs are transcribed by RNA polymerase II, and like mRNA, are 5'-capped, often spliced and polyadenylated [19]. Generally, compared to mRNA, IncRNAs display modest sequence conservation $[20,21]$. The reason for this may be that lncRNAs are free of codon preservation constraints [21]. Therefore, the sequence of lncRNAs appears to be less important than their secondary/tertiary structure, which plays a pivotal role [20,21].

In this paper, we present recently discovered information about the lncRNA interactome i.e., the cellular components that interact with lncRNA. We describe the interaction of the biomolecules, such as nucleic acids, sncRNA (miRNA), mRNA and DNA with lncRNA. A significant part of the review concerns the importance of lncRNA-protein complexes. Recently, a part of the lncRNA interactome has been found to be made out of short peptides, encoded inside lncRNA, and even small molecules. Their possible impact on IncRNA functions will be discussed. Recently, a part of the lncRNA interactome has been found to be made out of short peptides, encoded inside lncRNA, and even small molecules (Figure 1).
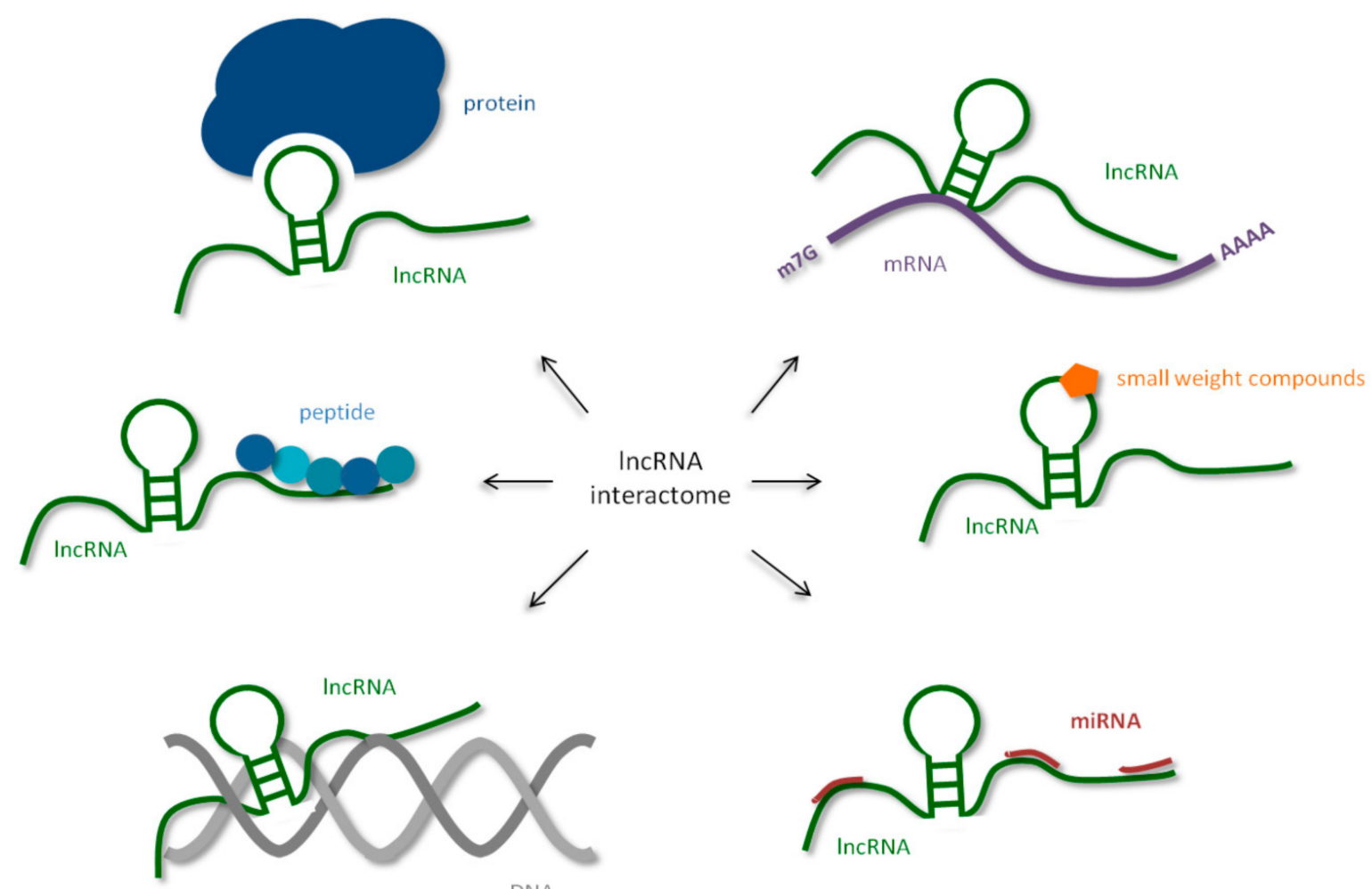

DNA

Figure 1. Human long non-coding RNAs (lncRNA) interactome, interaction of human lncRNA with cellular biomolecules.

IncRNAs have been discovered to be involved in divergent functions in the human organism, inter alia, during cell development and differentiation $[15,22,23]$. In addition, it appears that the mutation 
and dysregulation of many lncRNAs may be connected to serious and complex human diseases (Table 1).

Table 1. Examples of pathogenesis related to lncRNA dysregulation.

\begin{tabular}{|c|c|c|c|}
\hline Disease & LncRNA & Impact on Pathogenesis & Mechanism \\
\hline Colon cancer & DACOR1 [24,25] & Downregulated in colon tumors & $\begin{array}{c}\text { Interacts with and inhibits DNA } \\
\text { methyltransferase DNMT1 } \\
\text { HOTAIR may promote } \\
\text { dedifferentiation of lung }\end{array}$ \\
\hline Lung cancer & HOTAIR [26] & $\begin{array}{l}\text { Impacts proliferation, survival, } \\
\text { invasion, metastasis, and drug } \\
\text { resistance in lung cancer cells }\end{array}$ & $\begin{array}{l}\text { epithelial cells through two } \\
\text { distinct mechanisms, i.e., } \\
\text { transcriptional repression of } \\
\text { Hox5 and ubiquitin-mediated } \\
\text { proteolysis of Ataxin- }\end{array}$ \\
\hline Prostate cancer & LINCRNA-p21 [27] & $\begin{array}{l}\text { Decreases prostate cancer cell } \\
\text { proliferation }\end{array}$ & $\begin{array}{l}\text { LINCRNA-p21 inhibits many } \\
\text { genes expression in a } \\
\text { p53-dependent transcriptional } \\
\text { response }\end{array}$ \\
\hline Parkinson's disease & $\begin{array}{l}\text { H19, LincRNA-p21, } \\
\text { MALAT1, and SNHG1 [28] }\end{array}$ & $\begin{array}{c}\text { H19 is significantly } \\
\text { downregulated in Parkinson's } \\
\text { disease while LincRNA-p21, } \\
\text { Malat1 and SNHG1, are } \\
\text { significantly upregulated. }\end{array}$ & $\begin{array}{c}\text { Associated with synaptogenesis, } \\
\text { proliferation, apoptosis, } \\
\text { precedes Parkinson's disease }\end{array}$ \\
\hline Leukemia & MALAT1 [29] & $\begin{array}{l}\text { Inhibiting multiple myeloma } \\
\text { growth }\end{array}$ & $\begin{array}{l}\text { Involved in multiple myeloma } \\
\text { DNA repair and cell death. }\end{array}$ \\
\hline $\begin{array}{l}\text { Cardiovascular } \\
\text { diseases }\end{array}$ & GAS5 [30] & $\begin{array}{c}\text { Promotes the development and } \\
\text { progression of myocardial } \\
\text { infarctions }\end{array}$ & $\begin{array}{c}\text { Targeting of the } \\
\text { miR-525-5p/CALM2 axis }\end{array}$ \\
\hline Diabetes & HI-LNC901, PLUTO [31] & $\begin{array}{l}\text { Implicated in pancreatic islet } \\
\text { function }\end{array}$ & $\begin{array}{l}\text { Regulates the transcription of } \\
\text { PDX1 gene of pancreatic } \beta \text { cell }\end{array}$ \\
\hline AIDS & LINC00173 [32] & Regulates cytokines in T cells & $\begin{array}{l}\text { Presumably involved in } \\
\text { transcriptional regulation }\end{array}$ \\
\hline
\end{tabular}

Up to $70-80 \%$ of the human genome has been transcribed. However, only about $2 \%$ of the genome includes protein-coding genes (mRNA) [1,2]. ncRNAs account for the majority of the genome transcripts. The term ncRNA is usually used to refer to RNA that does not encode proteins, however this does not mean that such RNAs do not carry any information or have any functions [16,33,34]. ncRNAs are divided into housekeeping RNAs and regulatory RNAs, based on their functions. Housekeeping noncoding RNAs, including transfer RNAs (tRNAs), small nuclear RNAs (snRNAs), small nucleolar RNAs (snoRNAs) and ribosomal RNAs (rRNAs), are commonly expressed in a constitutive manner. Regulatory RNAs are ncRNAs with a strong regulatory impact on the expression of protein-coding genes. Based on their size, regulatory RNAs can be divided into two groups: sncRNAs ( $<200 \mathrm{nt})$ and $\operatorname{lncRNAs}$ (>200 nt). Small noncoding RNAs (sncRNAs) are a group which encompasses microRNAs (miRNAs), small interfering RNAs (siRNAs), Piwi associated RNAs (piRNAs), tRNA-derived fragments (tRFs) and circular RNAs (circRNAs). The second group, lncRNAs, which are larger than 200 nucleotides, as has been mentioned previously, do not have the ability to code protein.

Most IncRNAs have been found to be synthesized by RNA polymerase II under the control of the transcriptional activators of the SWI/SNF complex. However, some lncRNAs are transcribed by RNA polymerase III $[19,35]$. As has been already mentioned, the transcripts are capped, spliced and polyadenylated $[36,37]$.

\section{The LncRNA Interactome: The Nucleic Acid Story}

\subsection{Interactions of LncRNA with miRNAs, the ceRNA Hypothesis}

Despite over two decades of research, the role of non-coding RNAs in human development still remains a mystery. Most of the information available concerns the regulation of the activity of selected genes. There is a lot of evidence that suggests miRNAs contribute to this process, binding to specific mRNA 3' UTR regions and regulating the expression of these genes [7]. In 2011, Salmena et al. proposed a competitive, endogenous RNA (ceRNA) hypothesis [38], which is supported by a significant amount 
of experimental evidence [39-41]. According to this hypothesis, ncRNAs and miRNAs influence each other. When it comes to the mRNA pool, transcribed pseudogenes, IncRNA, circRNA and other RNAs, there is competition for the same pool of miRNA. When miRNA binds to mRNA, a "seed sequence" containing 2-8 nucleotides, which ensures efficient miRNA interaction, also referred to as the miRNA responsive element (MRE), is required [7,8,42]. It is already known that each mRNA may contain multiple MREs, and thus can be regulated by a number of miRNAs, while one miRNA can potentially regulate dozens of mRNAs. Many experimental findings support the idea that multiple ncRNAs, including sncRNAs, IncRNAs, and circRNAs, as well as pseudogenes, can act as so-called miRNA "sponges". By sharing identical MREs and competing for common miRNAs, they change miRNA's activity, which results in modified mRNA translation [41,43].

ceRNAs regulate each other through interactions with shared miRNAs, creating a large-scale regulatory network across the transcriptome, significantly expanding the functional genetic information in the genome (Table 2). In addition, the ceRNAs play an essential role in many biological processes, which is why the destruction of the balance between ceRNAs and miRNAs functions as a regulator. The lack of this balance plays a significant part in disease development and is found in many types of cancer [44].

Table 2. Selected lncRNAs interacting with microRNA (miRNA) and their functions.

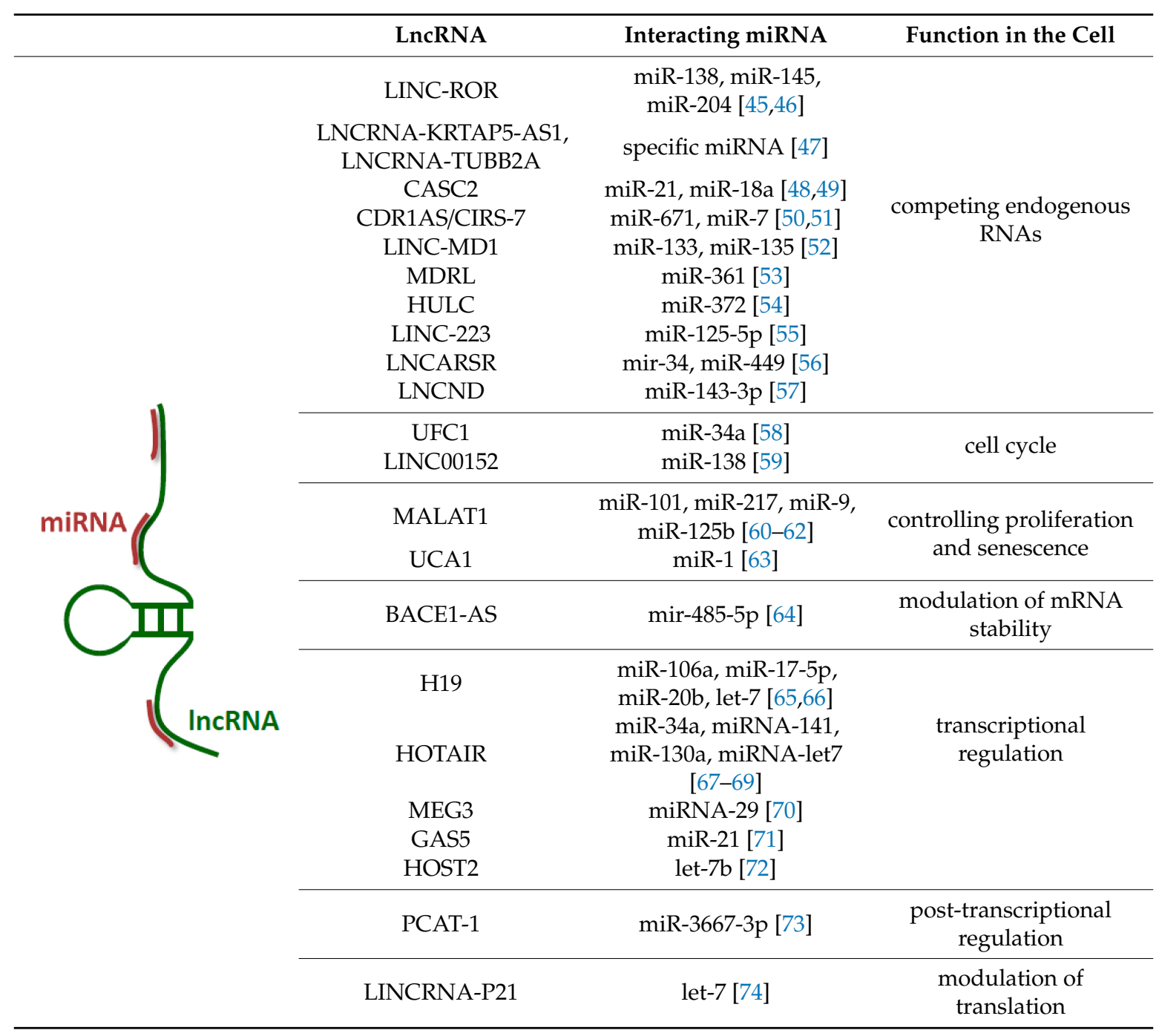

One important tool used to confirm miRNA-ceRNA interactions is the in silico analysis of the MREs shared by mRNA and ceRNA, such as IncRNA or circRNA. Several computer analysis 
approaches, such as MARIO, PARIS, LIGR etc, have already been successfully used in the past for performing such studies [75-77].

ncRNAs interact with each other during the biological processes that take place in the cell. In order to determine the interaction framework of different RNA molecules, and to determine which RNA molecules can anneal or hybridize to each other in the cell, the potential RNA-RNA interactions must be verified experimentally, in vivo. To achieve this goal, high-throughput sequencing of RNA, isolated by crosslinking and immunoprecipitation (HITS-CLIP) and the application of photoactivatable ribonucleoside enhanced crosslinking, as well as immunoprecipitation (PAR-CLIP) methods, were used $[65,78,79]$. PAR-CLIP, which is a modification of the HITS-CLIP method, utilizes the UV radiation of cell cultures, in the presence of psoralen derivatives $[53,76,79]$. These compounds specifically react with RNA, but not with proteins, and generate inter-strand cross-links between RNA's uridine bases. It has been shown that the integration of these crosslinking methods significantly enhances (over 20-fold) the search efficiency in terms of RNAs interacting with ceRNAs in liver cells, in comparison to in silico studies alone [80]. A more precise insight into miRNA-lncRNA interactions has recently been gained through the use of a combination of microarrays and the NGS method [81]. Using microarrays makes it possible for the expression of many sncRNA and lncRNAs to be analyzed in a single experiment. However, more information can be obtained through the analysis of NGS data. Although using both of these methods together is more informative, their high cost can be prohibitive.

The question is whether the ceRNA hypothesis can explain ncRNA's role in the progression of cancer. It has been calculated that more than $30 \%$ of miRNAs are involved in cancer regulation [82-84]. Evidence demonstrates that lncRNAs may acts as miRNAs decoy molecules, and may regulate its activity influencing cellular processes, including those that are associated with cancer $[39,85]$. Comprehensive analyses of ceRNA networks involving lncRNA-associated miRNA have been conducted for many diseases, such as ovarian and prostate cancer, glioblastoma, thyroid carcinoma, as well as breast, lung, kidney and gut cancers $[39,86,87]$. Usually, lncRNAs were aberrantly expressed and significantly correlated with the cancer prognosis. Recently, it has been shown that the MALAT1 lncRNA can sponge miR-211 as a ceRNA, and potentially up-regulate the PHF19 protein, a component of the polycomb complex, thus facilitating the progression of ovarian cancer [88]. Another HOTTIP IncRNA sponges miR-216a-5p, promoting prostate cancer cell proliferation, migration and invasion [89].

Although there are well-documented examples confirming the ceRNA hypothesis, some scientists find it controversial due to the fact that the expression of an additional mir122 target did not affect its abundance in the hepatocytes and liver [90]. In addition, this observation was confirmed for other ceRNAs; blocking the miRNA binding using antimir oligonucleotides had no physiological influence on miRNA function [91].

\subsection{Pairing LncRNAs with Messenger RNAs}

However, there is another mechanism for regulating RNA activity through its direct base pairing with lncRNA (Table 3). LncRNA and mRNA and the pre-mRNA complementary hybrid may participate in regulating translation by affecting mRNA splicing and editing as well as its stability [92,93]. 
Table 3. Some examples of lncRNA-mRNA pairing.

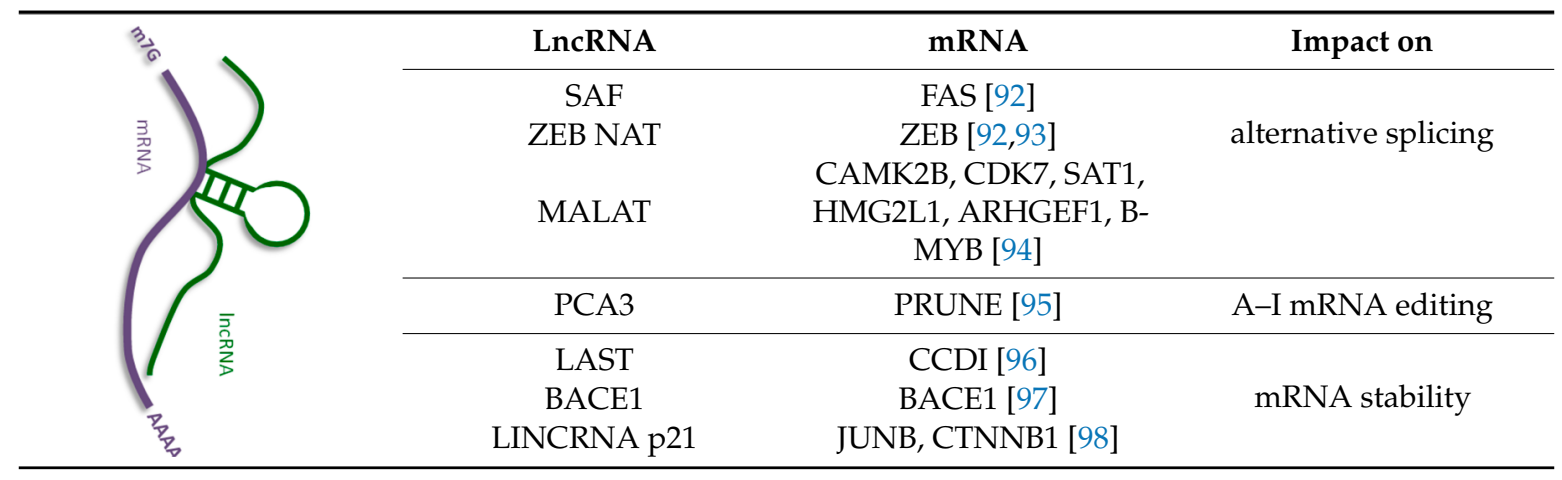

Most of the information concerning lncRNA-mRNA interactions come from bioinformatics analysis software such as: RNAplexn [99] and LncTar [100]. However, lncRNA-mRNA interactions need experimental verification via RNA probing or the aforementioned RNA-RNA crosslinking.

It has been predicted that IncRNA-pre-mRNA interactions may play an important role in alternative splicing. Since almost $90 \%$ of human genes are spliced alternatively, controlling this process is important for the development of organisms [92]. IncRNA may effectively regulate splicing; indeed, computer analyses indicate that out of about 24,500 genes, some 21,000 may be affected by the formation of IncRNA-mRNA duplexes. LncRNA may affect pre-mRNA splicing in two ways: by blocking spliceosome assembly involving intron-exon junction or by becoming the target for splicing factors [92]. For example, it has been suggested that MALAT1 lncRNA regulates the alternative splicing of pre-mRNA by controlling the functional levels of transcription factors [94].

The IncRNA-mRNA duplex is a good substrate for RNA adenosine deaminase, a double stranded specific enzyme, which converts adenine to inosine [101]. Inosine differs from adenine in that it possesses a carbonyl group instead of an amino group at position 6 of the purine ring. Such an RNA modification influences the base pairing. Adenine forms a base pair with uracil, unlike inosine, which pairs with cytosine. In the case of IncRNA A to I editing, most of the information comes from bioinformatics analyses [102]. It has been suggested that almost 200,000 editing sites occur in human IncRNAs, and the majority of them (65\%) are located within the sites, which significantly changes their secondary structure. Editing may alter the target sites of the lncRNAs and, therefore, the edited and non-edited transcripts may differ in terms of their functions [95,101].

Additionally, lncRNAs influence mRNA stability. Recently Cao et al. reported that IncRNA-assisted stabilization of transcripts (LAST) binds to the 5' UTR region of CCND1mRNA and protects it against possible nuclease targeting in cultured cells [94]. It appears that LAST interacts with other mRNAs. The overexpression of LAST IncRNA has also been observed in several cancer tissues.

\subsection{LncRNA-DNA Interactions}

Several mechanisms of lncRNA recruitment to genomic targets in lncRNA-DNA interactions have been proposed [103] (Table 4). One of them is the direct binding to DNA and the formation of a triple helix. The nature of the RNA-DNA-DNA triple helix formation is described in references $[104,105]$. Triplexes are formed by weaker, non-Watson-Crick base-pairs, Hoogsteen hydrogen bonds or reverse Hoogsteen hydrogen bonds between the Watson-Crick base-paired dsDNA and the third strand made up of RNA. Triplexes can be either parallel or antiparallel, based on the orientation of the third strand. The orientation of the third strand might be important for its functionality [106,107]. A couple of useful computer tools, which can be used to predict RNA-dsDNA triplex formation and IncRNA-DNA binding sites, such as GRIDseq [108], Triplexator [109], or LongTarget [110] are available. Several techniques, which can be used to search for lncRNA - DNA binding sites, such as Chromatin Isolation by RNA Purification (ChIRP), Chromatin Oligo Affinity Precipitation (ChOP), Capture Hybridisation 
Analysis of RNA Target (CHART) and RNA Antisense Purification (RAP), have been reviewed by Chu et al. [111] and Vance and Ponting [112].

Table 4. Examples of lncRNA interacting with DNA and their postulated function.

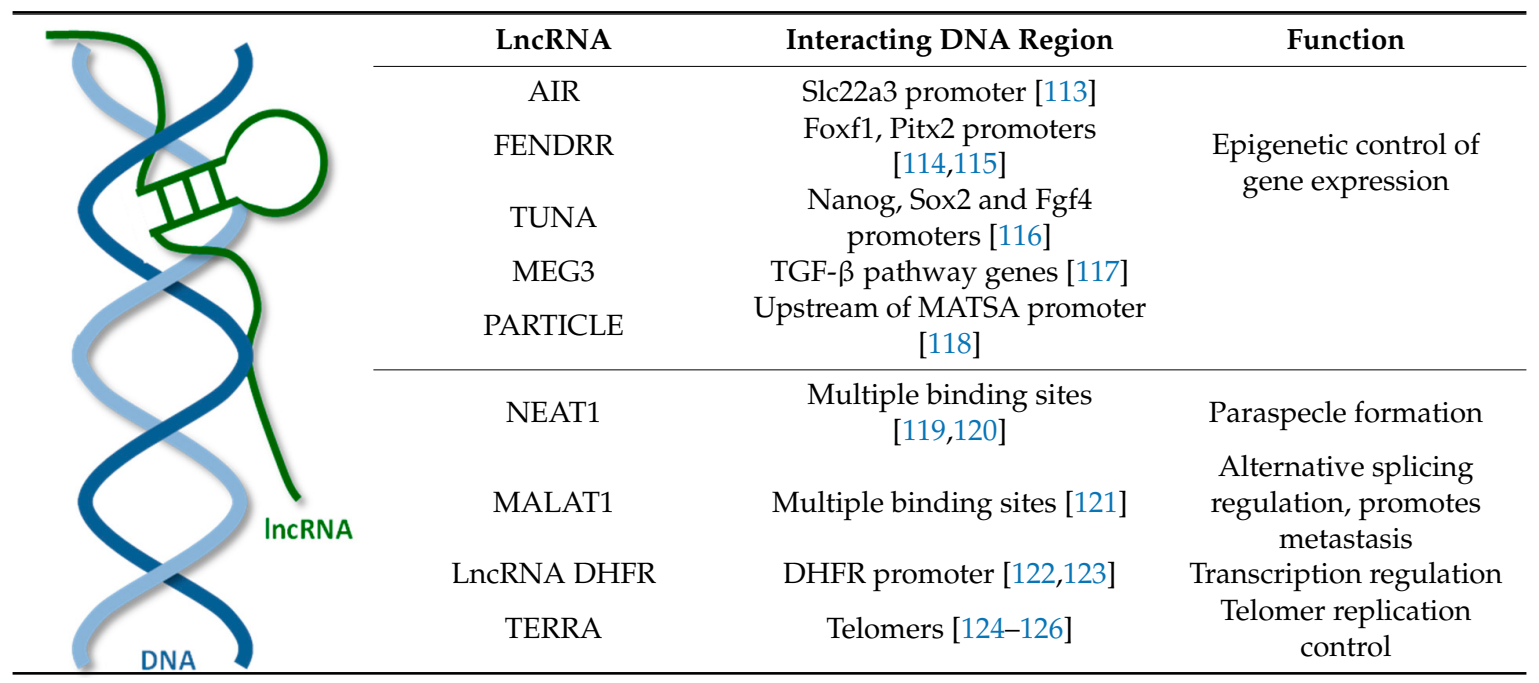

There are several examples where lncRNA can form a triple helix with dsDNA, such as FENDRR, DHFR, Khps, PARTICLE or NEG3. FENDRR IncRNA forms a triplex structure with gene (Foxf1, Pitx2) promoters, creating binding sites for the polycomb repressive complex (PRC2) and regulating the expression of its target genes $[114,115]$. FENDRR plays an important role in carcinogenesis. The decrease of this IncRNA is associated with gastric cancer. LncRNA DHFR has been shown to inhibit the transcription of $D f h r$ mRNA by creating a triplex structure with the DHFR promoter $[122,123]$. This interaction results in lncRNA DHFR binding to the TFIIB transcription factor, preventing the formation of a transcription initiation complex. The human heart tissue-specific lncRNA, Khps1, interacts with a homopurine stretch, upstream of the promoter of sphingosine kinase SPHK1, and the recruitment of p300/CBP (histone acetyltransferase) [113]. p300/CBP changes chromatin's state to active, which allows transcription factor E2F1 to bind and enhance SPHK1 expression. Promoter of MAT2A-antisense radiation-induced circulating lncRNA (PARTICLE) is expressed in response to low-dose irradiation [127]. It has been shown to form a triplex upstream of the methionine adenosyltransferase promoter (MAT2A). PARTICLE leads to the methylation of MAT2A by G9a and PRC2 complexes, which represses transcription. MEG3 binding sites have been shown to contain higher levels of GA-rich sequences. These sites help to guide MEG3 to its targets, by forming RNA-DNA triplexes [117]. Moreover, MEG3 regulates the activity of the TGF- $\beta$ genes cooperating with the PRC2 complex. AIR lncRNA, an antisense promoter transcript located in intron 2 of the insulin-like growth-factor type-2 receptor gene, has been found to occupy gene Slc22a3 promoter of cation transporter and recruit H3K9 histone methyltransferase G9a to epigenetically repress transcription [113]. Numerous genomic binding sites, such as NEAT1 and MALAT1, have also been identified for lncRNAs [119-121]. Most of the sites include active chromatin at highly expressed genes. Telomeric repeat-containing RNAs (TERRA), also known as TelRNAs, has been associated with telomeric chromatin, thus its involvement in telomere shortening has also been proposed [124-126]. In vitro experiments revealed that TERRA inhibits telomerase activity and is evolutionary conserved.

\section{LncRNA-Protein Interactome}

By defining the proteins that interact with lncRNA, it is possible to gain some insight into the molecular pathways, in which the lncRNA of interest might be involved [128]. Due to their significant size, reaching up to tens of thousands of nucleotides, lncRNAs have been shown to act as guides, signals, decoys and scaffolds for many different proteins $[129,130]$. Thus, it is important to detect which proteins 
form complexes with specific lncRNAs. There are a couple of approaches to try out when looking for lncRNA-protein interactions. The method to be chosen depends, among other things, on whether we focus on RNAs (RNA-centric methods) or proteins (protein-centric methods) [131]. Electrophoretic Mobility Shift Assay [EMSA] was the first method used to analyze RNA-protein interactions [132]. $\mathrm{A}^{32} \mathrm{P}$, fluorescent or chemiluminescent labeled lncRNA probe is incubated with cell lysate proteins and analyzed using non-denaturing, polyacrylamide gel electrophoresis [132-134]. The so-called pull down assay works in a similar fashion $[131,135]$. The biotin-labeled RNA is incubated with a cell lysis protein mixture to bind the interacting proteins. Subsequently, the complex is immobilized on streptavidin-agarose, purified, and detected using Western blotting [136]. Currently, there are three methods allowing for the detection of the IncRNA - protein interactome in use. The first method, immunoprecipitation, is usually used to prepare the RNA protein complexes. The second method combines crosslinking and immunoprecipitation (CLIP) [137,138]. This approach makes it possible to identify the proteins bound to the selected lncRNA, and to determine the protein binding sites in the IncRNA sequence. The last of the methods, Next Generation Sequencing (NGS), is used to analyze lncRNA - protein interactions, which significantly speeds up the analysis of RNA-protein complexes. There are several variants of the CLIP method, like HITS-CLIP, PAR-CLIP, iCLIP, etc. HITS-CLIP was developed as a genome-wide tool, designed to map protein-RNA binding sites in vivo [139]. The Photoactivatable-Ribonucleoside-Enhanced Crosslinking and Immunoprecipitation (PAR-CLIP) method uses cells cultured in the presence of nucleotide analogs, such as 4-thiouridine $\left(\mathrm{s}^{4} \mathrm{U}\right)$ or 6-thioguanosine $\left(\mathrm{s}^{6} \mathrm{G}\right)$. Thio-nucleotide analogs are incorporated into the newly synthesized RNAs. The crosslinking of proteins to modified lncRNAs makes it possible to precisely determine the type of protein and its binding site in the lncRNA sequence [140].

Because sequencing is an inherent part of all of them, it is crucial to pick the right data analysis methods in order to obtain the necessary information. In silico analysis makes the prediction of the structure, function or interaction of lncRNA-protein complex possible through screening the annotated sequences or structural motifs, like RNA-binding sites. There are also many user-friendly lncRNA databases, which collect information about sequences, which have already been annotated, such as lncRNAdb [141], LNCipedia [142], or NONCODE 2018 [143].

Due to the wide range in lncRNA size, which span from several hundred to several thousand nucleotides, there are many different sites proteins may bind to. Indeed, in the cell lncRNAs exist mainly in the form of RNA-protein complexes (Table 5). It has been suggested that RNA molecules are the perfect scaffolds for protein binding [144]. An estimated 5\% of lncRNAs may bind to about half of the interacting proteins. As has been shown in Table 3, there are lncRNAs that specifically bind one protein, and also lncRNAs which bind multiple proteins. For example, many proteins interact with HOTAIR IncRNA [34,145-147]. However, lncRNA, lnc-DC interacts only with the STAT 3 protein [148]. 
Table 5. IncRNA-protein complexes involved in the regulation of cellular functions.

\begin{tabular}{|c|c|c|c|c|}
\hline \multirow{19}{*}{ IncRNA } & LncRNA & LncRNA Length & $\begin{array}{l}\text { Interacting } \\
\text { Protein(s) }\end{array}$ & Function \\
\hline & KCNP1ot1 & $91.7 \mathrm{~kb}$ & PRC1, PRC2, G9a & \multirow{7}{*}{$\begin{array}{l}\text { Epigenetic control } \\
\text { of gene expression }\end{array}$} \\
\hline & XIST & $19 \mathrm{~kb}$ & $\begin{array}{l}\text { PRC2, hnRNP U, } \\
\text { YY1 [151.152] }\end{array}$ & \\
\hline & AIR & $4.3 \mathrm{~kb}$ & G9a $[153,154]$ & \\
\hline & ANRIL & $3.8 \mathrm{~kb}$ & PRC1 [155] & \\
\hline & HOTTIP & $3.8 \mathrm{~kb}$ & WDR5, MLL [156] & \\
\hline & HOTAIR & $2.4 \mathrm{~kb}$ & $\begin{array}{c}\text { PRC2, } \\
\text { LSD1/CoREST/REST } \\
{[145-147]}\end{array}$ & \\
\hline & H19 & $2.3 \mathrm{~kb}$ & PRC2 [157] & \\
\hline & DEANR1 & $4.9 \mathrm{~kb}$ & SMAD2/3 [158] & \multirow{6}{*}{$\begin{array}{l}\text { Transcription } \\
\text { regulation }\end{array}$} \\
\hline & LINCRNA-p21 & $2.7 \mathrm{~kb}$ & HnRNP $[159,160]$ & \\
\hline & PANDA & $1.5 \mathrm{~kb}$ & SAFA $[161,162]$ & \\
\hline & GAS5 & $1.0 \mathrm{kp}$ & GR (NR3C1) [163] & \\
\hline & LNC-DC & $630 \mathrm{bp}$ & STAT-3 [148] & \\
\hline & 7SK & $330 \mathrm{bp}$ & P-TEFb $[164,165]$ & \\
\hline & MIAT (Gomafu) & $10 \mathrm{~kb}$ & SF1 [166] & \multirow{3}{*}{ Alternative splicing } \\
\hline & MALAT (NEAT2) & $8.7 \mathrm{~kb}$ & SR [167] & \\
\hline & PNKY & $1.6 \mathrm{~kb}$ & hnRNP [168-170] & \\
\hline & $\mathrm{BC} 1$ & $152 \mathrm{bp}$ & $\begin{array}{c}\text { EIF4A/eIF4B, PABP } \\
\text { [171] }\end{array}$ & $\begin{array}{l}\text { Translation } \\
\text { regulation }\end{array}$ \\
\hline & THRIL & $2.9 \mathrm{~kb}$ & HnRNP [172] & Immune response \\
\hline
\end{tabular}

The results of the analyses presented in Table 3 clearly show that lncRNA-protein complexes regulate many cell processes: transcription and splicing, as well as gene expression. It should be emphasized that many human lncRNAs interact with the polycomb repressive protein complexes (PRC1 and PRC2) $[173,174]$. Both protein complexes interact with chromatin and are involved in chromatin remodeling as well as the epigenetic regulation of gene expression via DNA and histone modification [175]. A variety of molecular investigations authenticate the association between lncRNAs-such as HOTAIR, Kcnq1, Air and chromatin remodeling complexes, such as PRC1 and PRC2, which mediate ubiquitination and histone methylation, respectively (Table 4). At the Kcnq1 locus, the lncRNA Kcnq1ot1 interacts with members of the PRC1 and PRC2 complex proteins $[149,150]$. At the Igf2r locus, Air lncRNA associates with the histone methyltransferase, G9a [154]. HOTAIR recruits PRC2 at the HOXD locus, to induce the silencing of the target genes $[145,147]$. Another example is the heterogeneous nuclear ribonucleoprotein complexes (hnRNP), which encompass several RNA binding proteins involved in gene expression, including pre-mRNA processing, mRNA stability, and translation $[129,176]$. However, a recent analysis of significant amounts of literature, concerning the interactions of PKC2 proteins with lncRNAs, showed that these interactions are either promiscuous or that the methods used to detect them have a lot of noise [177].

The interactions of the hnRNP protein with various lncRNAsplay a significant role in many cell functions [178]. As mentioned in Table 4, hnRNP interacts with LINC-p21 as well as PNKY IncRNA, thus regulating transcription and alternative splicing, respectively $[159,160]$. In addition, the THRIL lncRNA (TNF $\alpha$ and hnRNPL related immunoregulatory lncRNA) plays a key role in innate immune responses as well as in inflammatory diseases in humans [172]. To summarize, lncRNAs are targets of many proteins, whereas lncRNA-protein complexes perform many functions in the cell by participating in various cellular processes (Table 5). 


\section{Peptides-A New Factor in the LncRNA Interactome?}

LncRNAs are RNAs defined as having a size exceeding 200 nucleotides and being a non-coding part of the genome. This means that lncRNAs do not encode proteins, i.e., they do not harbor an open reading frame. However, recent studies have revealed that a subset of lncRNAs that code small peptides, usually shorter than 100 amino acids, exists [179-181]. These lnRNAs are localized in the cytosol and contain only a single-exon-sequence coding peptide.

The detection of lncRNA-origin peptides is not easy, because computer analyses predict many Open Reading Frames (ORF), however, only a few of them are actively translated. It has been calculated that about $23 \%$ of the transcribed lncRNAs have been translated [182]. Moreover, the expression of many peptides is weak, and they are difficult to detect, especially in the case of peptides that lack sequence homologies to known proteins. Many methods for detecting peptide expression combine bioinformatic algorithms and experimental verification. An excellent overview of bioinformatics tools used to search for potential ORF in lncRNAs was put forth by Choi et al. [183]. The simplest way of verifying the predicted ORF involves in vitro translation methods. Constructing a template and performing translation with the use of rabbit reticulocyte, with ${ }^{35} \mathrm{~S}$ methionine and SDS electrophoresis, makes it possible to determine the size of the predicted peptide [184]. This is important, because due to its size (>200 nucleotides), lncRNA contains many AUG start codons and the encoded peptides vary in length.

The identification of peptides in protein samples isolated from tissues or culture cells, is possible by applying the Western blot method with the appropriate antibodies, following peptide purification. Moreover, the development of mass spectrometry techniques has made this method perfect for identifying such peptides [185]. Another approach involves the use of the ribosome profiling, in connection with NGS methods [186]. In this approach, the RNAs bound to polysomes are purified using sucrose gradient centrifugation, and then, after nuclease digestion, the RNA fragment protected by ribosomes is recovered. These RNA fragments are sources for library preparation and sequencing and the use of bioinformatics tools in genome mapping, which makes the identification of the ORF region possible.

The fundamental issue associated with these bifunctional RNAs is the determination of the role of lncRNA and its coding peptide. The initial question is whether they act as a complex or as separate compounds. The next question is whether the maternal lncRNA, which contains ORF, interacts with its own peptide.

Analysis of available data indicates that the size of the peptide is not connected with the size of the maternal lncRNAs. An $8.7 \mathrm{~kb}$ long MALAT1 lncRNA codes a peptide containing 213 amino acids, while the four times shorter XGAT1 lncRNA [2.1 kb] codes a peptide containing 210 amino acids, which is identical in size. [183,187]. Dissection impact on the cell selected lncRNA and translated from its ORF peptide is difficult. Recently, the role some peptides play in cell functions has been explained. The 46 amino acid peptide, myoregulin, which is encoded by a $16.5 \mathrm{~kb}$ long skeletal, muscle-specific IncRNA, LINC00948, regulates the regeneration of skeletal muscles by interacting with sarcoplasmic reticulum $\mathrm{Ca}^{2+}$-ATPase (SERCA) [188], lysosomal v-ATPase [189] or removing SERCA inhibitors [190].

Moreover, only the HOXB-AS3 peptide, not lncRNA, is critical for suppressing colon cancer growth, by blocking pyruvate kinase $\mathrm{M}[\mathrm{PKM}]$ splicing, miR-18a processing, and the subsequent glucose metabolism reprogramming [191]. On the other hand, HOXB-AS3 IncRNA could also regulate the cell cycle progression of OCI-AML3 cells in Npm1 mutated acute myeloid leukemia. Observations suggest that there might be an unknown interaction between the lncRNA and peptides, however, this hypothesis requires further investigation.

\section{Do Small Compounds Influence LncRNA Activity?}

Many RNAs form constrained structures containing "pockets" that bind small molecular weight compounds. This repertoire of RNAs includes long RNAs and small RNAs, such as rRNA and mRNA, as well as ribozymes, riboswitches, and aptamers, which were discovered during the last twenty 
years $[192,193]$. The question is whether chemical compounds with a low molecular weight, which regulate lncRNA activity by structure-specific binding, really exist.

The recently determined $3.1 \AA$ resolution MALAT1 crystal structure revealed a constrained structure, containing a bipartite triple helix at the $3^{\prime}$ end [194]. The disruption of the stability of the helix by a point mutation resulted in MALAT1 accumulation in the cell [195]. The recognition of the triple helix by a methyltransferase enzyme strongly supported its functional role [196]. Small molecules, which destabilize this MALAT1 structural element, make it possible to regulate lncRNA functions [197]. XIST is one of the best-characterized lncRNAs. It functions as the major effector of the $\mathrm{X}$ chromosome inactivation $(\mathrm{XCI})$ process in mammals. Specific structural domains, namely six tandem hairpin repeats (A-F), are crucial to its functioning in the XCI process. Structural insight into the $\mathrm{A}$ and $\mathrm{F}$ repeat region of the hairpins revealed an intricate architecture within specific functional modules [198]. In cellulo chemical probing of the entire 18k.b. transcript enabled the discovery of an additional domain at the 3' end, connected with XIST localization [199]. Decoding the structure should make it possible to identify small molecules, which have the ability to recognize lncRNA's structural elements. It will also elucidate the role they play in development and disease.

Research on the lncRNA structure using low molecular weight compounds (DMS, DEPC, $\mathrm{Pb} 2+$ ions, etc) has shown it is conserved [200]. This means that structural elements, such as loops, bulges and base-paired regions, which occur in small RNAs, are also found numerous times in IncRNA and may be places where various small molecules bind. Information concerning the interactions of small compounds with lncRNA is still limited. Fatemi et al. identified small molecules, which bind to the lncRNA-protein complex, using high-throughput compound screening methods, i.e., the Amplified Luminescent Proximity Homogeneous Assay [201]. They reported on the specific and quantifiable binding of the brain-derived neurotrophic factor antisense IncRNA to a component of the PCR2 complex, protein EZH2, and also identified a small-molecule inhibitor-ellipticine, that upregulates its downstream target genes. It was also reported that telRNAs, which form the G-quadruplex, target alkaloid quindoline derivatives [202]. The binding of this compound inhibits proliferation and causes G2/M phase arrest in osteosarcoma cancer cells as well as induces DNA damage response and apoptosis. Recently, it has been shown by Shi et al. [203] that the binding of fluorescent peptide derivative NP-C86 to GAS5 IncRNA stabilizes its structure.

\section{Concluding Remarks and Perspectives}

Although $70-80 \%$ of the genome has been transcribed, it has been discovered that only $2 \%$ of the genome encodes protein sequences. $80 \%$ of the remaining ncRNA pool is made up of lncRNA. As this review shows, lncRNAs are not just cellular junk but are involved in many processes such as transcription, translational regulation or in cell development in general. Long noncoding RNA has been shown to interact with a range of cell biomolecules such as other RNAs (miRNAs, mRNAs) and DNA to form the lncRNA interactome, which is involved in life processes. A significant part of the IncRNA interactome is associated with the formation of complexes with proteins or even, as has been recently discovered, peptides. Given the size of the entire lncRNA interactome, the examples that have been studied to date are just the tip of the iceberg. The fact that interference disorders in the lncRNA interactome are the cause of various pathogenesis pathways, including cancer, neurodegenerative, and immunological diseases, is also an impetus for further research.

In the future, one can expect new lncRNA annotation tools will be developed, such as new DNA and RNA sequencing methods (nanopore sequencing) and new bioinformatics methods [204,205]. The development of new methods of analysis, like mass spectroscopy makes it possible to detect biomolecules that bind to lncRNA, including proteins, peptides and low-molecular compounds. It is also important to determine how the lncRNA interactome influences cellular processes, as well as the impact it has on various stages of the organism's development. New DNA editing methods (CRISP/Cas9 and RNA (CRISP/Cas13 [206,207] could be helpful in achieving these goals. The destruction of genes encoding proteins or lncRNA and miRNA seems to be a powerful method of 
testing the lncRNA interactome. It seems particularly important to determine the role of lncRNA in the pathogenesis of various diseases and as a biomarker of the disease state, for example, during the cancerogenesis processes. However, modulating lncRNA activity with low-molecular compounds (alkaloids, antibiotics, peptides, etc.) may be used for therapeutic purposes in the future.

To summarize, the lncRNA interactome is a large group of biomolecules, related to and interacting with lncRNA, that play a variety of roles in cell development and the pathogenesis of various diseases.

Author Contributions: M.K., M.K.K. and M.E.K. wrote the manuscript, prepared the figures and reviewed the manuscript. J.W. supervised and finally accepted the manuscript. All the authors have read and approved the manuscript submitted to the journal. All authors have read and agreed to the published version of the manuscript.

Funding: This work was supported by the Polish National Centre of Science, grant number 2016/21/NZ2/03468 to J.W.

Acknowledgments: We thank B. Imiołczyk for critically reading the manuscript.

Conflicts of Interest: The authors declare no conflict of interest. The funders had no role in the design of the study; in the collection, analyses, or interpretation of data; in the writing of the manuscript, or in the decision to publish the results.

\section{References}

1. Djebali, S.; Davis, C.A.; Merkel, A.; Dobin, A.; Lassmann, T.; Mortazavi, A.; Xue, C. Landscape of transcription in human cells. Nature 2012, 489, 101-108. [CrossRef] [PubMed]

2. Lander, E.S.; Linton, L.M.; Birren, B.; Nusbaum, C.; Zody, M.C.; Baldwin, J.; Funke, R. Initial sequencing and analysis of the human genome. Nature 2001, 409, 860-921. [PubMed]

3. Palazzo, A.F.; Lee, E.S. Non-coding RNA: What is functional and what is junk. Front. Genet. $2015,6,2$. [CrossRef]

4. Hombach, S.; Kretz, M. Non-coding RNAs: Classification, biology and functioning. Adv. Exp. Med. Biol. 2016, 937, 3-17.

5. Cech, T.R.; Steitz, J.A. The noncoding RNA revolution-trashing old rules to forge new ones. Cell 2014, 157, 77-94. [CrossRef] [PubMed]

6. Fire, A.; Xu, S.; Montgomery, M.K.; Kostas, S.A.; Driver, S.; Mello, C.C. Potent and specific genetic interference by double-stranded RNA in Caenorhabditis elegans. Nature 1998, 391, 806-811. [CrossRef] [PubMed]

7. Krol, J.; Loedige, I.; Filipowicz, W. The widespread regulation of microRNA biogenesis, function and decay. Nat. Rev. Genet. 2010, 11, 597-610. [CrossRef]

8. $\mathrm{Pu}, \mathrm{M}$.; Chen, J.; Tao, Z.; Miao, L.; Qui, X.; Wang, Y.; Ren, J. Regulatory network of miRNA on its target: Coordination between transcriptional and post-transcriptional regulation of gene expression. Cell. Mol. Life Sci. 2019, 76, 441-451. [CrossRef]

9. Huyn, S. Small RNA pathways that protect the somatic genome. Int. J. Mol. Sci. 2017, 18, 912. [CrossRef]

10. Pillai, R.S.; Chuma, S. piRNAs and their involvement in male germline development in mice. Dev. Growth Differ. 2012, 54, 78-92. [CrossRef]

11. Weick, E.M.; Miska, E.A. piRNAs: From biogenesis to function. Development 2014, 141, 3458-3471. [CrossRef] [PubMed]

12. Iwasaki, Y.W.; Siomi, M.C.; Siomi, H. PIWI-interacting RNA: Its biogenesis and functions. Annu. Rev. Biochem. 2015, 84, 405-433. [CrossRef] [PubMed]

13. Gebetsberger, J.; Polacek, N. Slicing tRNAs to boost functional ncRNA diversity. RNA Biol. 2013, 10, 1798-1806. [CrossRef] [PubMed]

14. Oberbauer, V.; Schaefer, R.S. tRNA-Derived Small RNAs: Biogenesis, Modification, Function and Potential Impact on Human Disease Development. Genes 2018, 9, 607. [CrossRef]

15. Wu, H.; Yang, L.; Chen, L.L. The diversity of long noncoding RNAs and their generation. Trends Genet. 2017, 33, 540-552. [CrossRef]

16. Uszczyńska-Ratajczak, B.; Lagarde, J.; Frankish, A.; Guido, R.; Johnson, R. Towards a complete map of the human long non-coding RNA transcriptome. Nature Rev. Genet. 2018, 18, 535-548. [CrossRef] 
17. Engreitz, J.M.; Pandya-Jones, A.; McDonel, P.; Shishkin, A.; Sirokman, K.; Surka, C.; Kadri, S.; Xing, J.; Goren, A.; Lander, E.S.; et al. The Xist lncRNA exploits three-dimensional genome architecture to spread across the X chromosome. Science 2013, 341, 1237973. [CrossRef]

18. Carrieri, C.; Cimatti, L.; Biagioli, M.; Beugnet, A.; Zucchelli, S.; Fedele, S.; Pesce, E.; Ferrer, I.; Collavin, L.; Santoro, C.; et al. Long non-coding antisense RNA controls Uchl1 translation through an embedded SINEB2 repeat. Nature 2012, 491, 454-457. [CrossRef]

19. Quinn, J.J.; Chang, H.Y. Unique features of long non-coding RNA biogenesis and function. Nat. Rev. Genet. 2017, 17, 47-62. [CrossRef]

20. Chodroff, R.A.; Goodstadt, L.; Sirey, T.M.; Oliver, P.L.; Davies, K.E.; Green, E.D.; Molnár, Z.; Ponting, C.P. Long noncoding RNA genes: Conservation of sequence and brain expression among diverse amniotes. Genome Biol. 2010, 11, R72. [CrossRef]

21. Necsulea, A.; Kaessmann, H. Evolutionary dynamics of coding and non-coding transcriptomes. Nat. Rev. Genet. 2014, 15, 734-748. [CrossRef] [PubMed]

22. Yan, P.; Luo, S.; Lu, J.Y.; Shen, X. Cis- and trans-acting lncRNAs in pluripotency and reprogramming. Curr. Opin. Genet. Dev. 2017, 46, 170-178. [CrossRef] [PubMed]

23. Sun, C.; Huang, L.; Li, Z.; Leng, K.; Xu, Y.; Jiang, X.; Cui, Y. Long non-coding RNA MIAT in development and disease: A new player in an old game. J. Biomed. Sci. 2017, 25, 23. [CrossRef] [PubMed]

24. Morlando, M.; Fatica, A. Alteration of Epigenetic Regulation by Long Noncoding RNAs in Cancer. Int. J. Mol. Sci. 2018, 19, 570. [CrossRef] [PubMed]

25. Jang, Y.Y.; Junjie, P.; Sanjun, C.; Ma, Y. Long non-coding RNAs in colorectal cancer: Progression and future directions. J. Cancer 2017, 8, 3212-3225.

26. Loewen, G.; Jayawickramarajah, J.; Zhuo, Y.; Shan, B. Functions of lncRNA HOTAIR in lung cancer. J. Hematol Oncol. 2014, 7, 90. [CrossRef] [PubMed]

27. Wang, X.; Ruan, Y.; Wang, X.; Zhao, W.; Jiang, Q.; Jiang, C. Long intragenic non-coding RNA lincRNA-p21 suppresses development of human prostate cancer. Cell Prolif. 2017, 50, e12318. [CrossRef]

28. Li, L.; Zhuang, Y.; Zhao, X.; Li, X. Long non-coding RNA in neuronal development and neurological disorders. Front. Genet. 2018, 9, 744. [CrossRef]

29. Hu, Y.; Lin, J.; Fang, H.; Fang, J.; Li, C.; Chen, W.; Liu, S.; Ondrejka, S.; Gong, Z.; Reu, F.; et al. Targeting the MALAT1/PARP1/LIG3 complex induces DNA damage and apoptosis in multiple myeloma. Leukemia 2018, 32, 2250-2262. [CrossRef]

30. Zhang, Y.; Hou, Y.M.; Gao, F.; Xiao, J.W.; Li, C.C.; Tang, Y. lncRNA GAS5 regulates myocardial infarction by targeting the miR-525-5p/CALM2 axis. J. Cell Biochem. 2019, 120, 18678-18688. [CrossRef]

31. Mirza, A.H.; Kaur, S.; Pociot, F. Long non-coding RNAs as novel players in $\beta$ cell function and type 1 diabetes. Hum. Genomics 2017, 11, 17. [CrossRef] [PubMed]

32. Postler, T.S.; Pantry, S.N.; Desrosiers, R.C.; Ghosh, S. Identification and characterization of a long non-coding RNA up-regulated during HIV-1 infection. Virology 2017, 511, 30-39. [CrossRef] [PubMed]

33. Somarowthu, S.; Legiewicz, M.; Chillón, I.; Marcia, M.; Liu, F.; Pyle, A.M. HOTAIR forms an intricate and modular secondary structure. Mol. Cell 2015, 58, 353-361. [CrossRef] [PubMed]

34. Chen, L.L. Linking long noncoding RNA localization and function. Trends Biochem. Sci. 2016, 41, 761-772. [CrossRef] [PubMed]

35. Long, Y.; Wang, X.; Youmans, D.T.; Cech, T.R. How do lncRNAs regulate transcription? Adv. Sci. 2017, 3, eaao2110. [CrossRef] [PubMed]

36. St Laurent, G.; Wahlestedt, C.; Kapranov, P. The landscape of long non-coding RNA classification. Trends Genet. 2015, 31, 239-251. [CrossRef] [PubMed]

37. Schulz, D.; Schwalb, B.; Kiesel, A.; Baejen, C.; Torkler, P.; Gagneur, J.; Soeding, J.; Cramer, P. Transcriptome surveillance by selective termination of noncoding RNA synthesis. Cell 2013, 155, 1075-1087. [CrossRef]

38. Salmena, L.; Poliseno, L.; Tay, Y.; Kats, L.; Pandolfi, P.P. A ceRNA hypothesis: The Rosetta stone of a hidden RNA language? Cell 2011, 146, 353-358. [CrossRef]

39. Tay, Y.; Rinn, J.; Pandolfi, P.P. The multilayered complexity of ceRNA crosstalk and competition. Nature 2014, 505, 344-352. [CrossRef]

40. Smillie, C.L.; Sirey, T.; Ponting, C.P. Complexities of post-transcriptional regulation and the modeling of ceRNA crosstalk. Crit. Rev. Biochem. Mol. Biol. 2018, 53, 231-245. [CrossRef] 
41. Ulitsky, I. Interactions between short and long noncoding RNAs. FEBS Lett. 2018, 592, 2874-2883. [CrossRef] [PubMed]

42. Stroynowska-Czerwinska, A.; Fiszer, A.; Krzyżosiak, W.J. The panorama of miRNA-mediated mechanisms in mammalian cells. Cell Mol. Life Sci. 2014, 71, 2253-2270. [CrossRef] [PubMed]

43. Chan, J.J.; Tay, Y. Noncoding RNA: RNA regulatory networks in cancer. Int. J. Mol. Sci. 2018, $19,1310$. [CrossRef] [PubMed]

44. Qi, X.; Zhang, D.H.; Wu, N.; Xiao, J.H.; Wang, X.; Ma, W. ceRNA in cancer: Possible functions and clinical implications. J. Med. Genet. 2015, 52, 710-718. [CrossRef] [PubMed]

45. Feng, L.; Shi, L.; Lu, Y.F.; Wang, B.; Tang, T.; Fu, W.M.; He, W.; Li, G.; Zhang, J.F. Linc-ROR promotes osteogenic differentiation of mesenchymal stem cells by functioning as a competing endogenous RNA for miR-138 and miR-145. Mol. Ther. Nucleic Acids 2018, 11, 345-353. [CrossRef] [PubMed]

46. Gao, H.; Wang, T.; Zhang, P.; Shang, M.; Gao, Z.; Yang, F.; Liu, R. Linc-ROR regulates apoptosis in esophageal squamous cell carcinoma via modulation of p53 ubiquitination by targeting miR-204-5p/MDM2J. Cell Physiol. 2019. [CrossRef]

47. Song, Y.X.; Sun, J.X.; Zhao, J.H.; Yang, Y.C.; Shi, J.X.; Wu, Z.H.; Chen, X.W.; Gao, P.; Miao, Z.F.; Wang, Z.N. Non-coding RNAs participate in the regulatory network of CLDN4 via ceRNA mediated miRNA evasion. Nat. Commun. 2017, 8, 289. [CrossRef]

48. Wang, P.; Liu, Y.H.; Yao, Y.L.; Li, Z.; Li, Z.Q.; Ma, J.; Xue, Y.X. Long non-coding RNA CASC2 suppresses malignancy in human gliomas by miR-21. Cell Signal. 2015, 27, 275-282. [CrossRef]

49. Huang, G.; Wu, X.; Li, S.; Xu, X.; Zhu, H.; Chen, X. The long noncoding RNA CASC2 functions as a competing endogenous RNA by sponging miR-18 a in colorectal cancer. Sci. Rep. 2016, 6, 26524. [CrossRef]

50. Hansen, T.B.; Wiklund, E.D.; Bramsen, J.B.; Villadsen, S.B.; Statham, A.L.; Clark, S.J.; Kjems, J. miRNA-dependent gene silencing involving Ago2-mediated cleavage of a circular antisense RNA. EMBO J. 2011, 30, 4414-4422. [CrossRef]

51. Hansen, T.B.; Jensen, T.I.; Clausen, B.H.; Bramsen, J.B.; Finsen, B.; Damgaard, C.K.; Kjems, J. Natural RNA circles function as efficient microRNA sponges. Nature 2013, 495, 384-388. [CrossRef] [PubMed]

52. Cesana, M.; Cacchiarelli, D.; Legnini, I.; Santini, T.; Sthandier, O.; Chinappi, M.; Tramontano, A.; Bozzoni, I. A long noncoding RNA controls muscle differentiation by functioning as a competing endogenous RNA. Cell 2011, 147, 358-369. [CrossRef]

53. Wang, K.; Sun, T.; Li, N.; Wang, Y.; Wang, J.X.; Zhou, L.Y.; Long, B.; Liu, C.Y.; Liu, F.; Li, P.F. MDRL IncRNA regulates the processing of miR-484 primary transcript by targeting miR-361. PLoS Genet. 2014, 10, e1004467. [CrossRef]

54. Wang, J.; Liu, X.; Wu, H.; Ni, P.; Gu, Z.; Qiao, Y.; Chen, N.; Sun, F.; Fan, Q. CREB up-regulates long non-coding RNA, HULC expression through interaction with microRNA-372 in liver cancer. Nucleic Acids Res. 2010, 38, 5366-5383. [CrossRef] [PubMed]

55. Mangiavacchi, A.; Sorci, M.; Masciarelli, S.; Larivera, S.; Legnini, I.; Iosue, I.; Bozzoni, I.; Fazi, F.; Fatica, A. The miR-223 host non-coding transcript linc-223 induces IRF4 expression in acute myeloid leukemia by acting as a competing endogenous RNA. Oncotarget 2016, 7, 60155-60168. [CrossRef] [PubMed]

56. Qu, L.; Ding, J.; Chen, C.; Wu, Z.J.; Liu, B.; Gao, Y.; Chen, W.; Liu, F.; Sun, W.; Li, X.F. Exosome-transmitted lncARSR promotes sunitinib resistance in renal cancer by acting as a competing endogenous RNA. Cancer Cell 2016, 29, 653-668. [CrossRef] [PubMed]

57. Rani, N.; Nowakowski, T.J.; Zhou, H.; Godshalk, S.E.; Lisi, V.; Kriegstein, A.R.; Kosik, K.S. A primate lncRNA mediates notch signaling during neuronal development by sequestering miRNA. Neuron 2016, 90, 1174-1188. [CrossRef] [PubMed]

58. Cao, C.; Sun, J.; Zhang, D.; Guo, X.; Xie, L.; Li, X.; Wu, D.; Liu, L. The long intergenic noncoding RNA UFC1, a target of microRNA 34a, interacts with the mRNA stabilizing protein HuR to increase levels of beta-catenin in HCC cells. Gastroenterology 2015, 148, 415-426. [CrossRef]

59. Cai, Q.; Wang, Z.; Wang, S.; Weng, M.; Zhou, D.; Li, C.; Wang, J.; Chen, E.; Quan, Z. Long non-coding RNA LINC00152 promotes gallbladder cancer metastasis and epithelial-mesenchymal transition by regulating HIF-1 $\alpha$ via miR-138. Open Biol. 2017, 7, 160247. [CrossRef]

60. Wang, X.; Li, M.; Wang, Z.; Han, S.; Tang, X.; Ge, X.; Zhou, L.; Zhou, C.; Yuan, Q.; Yang, M. Silencing of long noncoding RNA MALAT1 by miR-101 and miR- 217 inhibits proliferation, migration and invasion of esophageal squamous cell carcinoma cells. J. Biol. Chem. 2015, 290, 3925-3935. [CrossRef] 
61. Leucci, E.; Patella, F.; Waage, J.; Holmstrøm, K.; Lindow, M.; Porse, B.; Kauppinen, S.; Lund, A.H. MicroRNA-9 targets the long non-coding RNA MALAT1 for degradation in the nucleus. Sci. Rep. 2013, 3, 2535. [CrossRef] [PubMed]

62. Han, Y.; Liu, Y.; Zhang, H.; Wang, T.; Diao, R.; Jiang, Z.; Gui, Y.; Cai, Z. Hsa-miR-125b suppresses bladder cancer development by down- regulating oncogene SIRT7 and oncogenic long noncoding RNA MALAT1. FEBS Lett. 2013, 87, 3875-3882. [CrossRef] [PubMed]

63. Wang, T.; Yuan, J.; Feng, N.; Li, Y.; Lin, Z.; Jiang, Z.; Gui, Y. Hsa-miR-1 downregulates long non-coding RNA urothelial cancer associated 1 in bladder cancer. Tumor Biol. 2014, 35, 10075-10084. [CrossRef] [PubMed]

64. Faghihi, M.A.; Zhang, M.; Huang, J.; Modarresi, F.; van der Brug, M.P.; Nalls, M.A.; Cookson, M.R.; St-Laurent, G.; Wahlestedt, C. Evidence for natural antisense transcript-mediated inhibition of microRNA function. Genome Biol. 2011, 11, R56. [CrossRef]

65. Imig, J.; Brunschweiger, A.; Brümmer, A.; Guennewig, B.; Mittal, N.; Kishore, S.; Tsikrika, P.; Gerber, A.P.; Zavolan, M.; Hall, J. miR-CLIP captureof a miRNAtargetomeuncovers a lincRNA H19-miR- 106a interaction. Nat. Chem. Biol. 2015, 11, 107-114. [CrossRef]

66. Kallen, A.N.; Zhou, X.B.; Xu, J.; Qiao, C.; Ma, J.; Yan, L.; Lu, L.; Liu, C.; Yi, J.S.; Zhang, H.; et al. The imprinted H19 lncRNA antagonizes let-7 microRNAs. Mol. Cell 2013, 52, 101-112. [CrossRef]

67. Chiyomaru, T.; Yamamura, S.; Fukuhara, S.; Yoshino, H.; Kinoshita, T.; Majid, S.; Saini, S.; Chang, I.; Tanaka, Y.; Enokida, H.; et al. Genistein inhibits prostate cancer cell growth by targeting miR- 34a and oncogenic HOTAIR. PLoS ONE 2013, 8, e70372. [CrossRef]

68. Ma, M.Z.; Li, C.X.; Zhang, Y.; Weng, M.Z.; Zhang, M.D.; Qin, Y.Y.; Gong, W.; Quan, Z.W. Long non-coding RNA HOTAIR, a c-Myc activated driver of malignancy, negatively regulates miRNA-130a in gallbladder cancer. Mol. Cancer 2014, 13, 156. [CrossRef]

69. Yoon, J.H.; Abdelmohsen, K.; Kim, J.; Yang, X.; Martindale, J.L.; Tominaga-Yamanaka, K.; White, E.J.; Orjalo, A.V.; Rinn, J.L.; Kreft, S.G.; et al. Scaffold function of long non-coding RNA HOTAIR in protein ubiquitination. Nat. Commun. 2013, 4, 2939. [CrossRef]

70. Braconi, C.; Kogure, T.; Valeri, N.; Huang, N.; Nuovo, G.; Costinean, S.; Negrini, M.; Miotto, E.; Croce, C.M.; Patel, T. microRNA-29 can regulate expression of the long non-coding RNA gene MEG3 in hepatocellular cancer. Oncogene 2011, 30, 4750-4756. [CrossRef]

71. Zhang, Z.; Zhu, Z.; Watabe, K.; Zhang, X.; Bai, C.; Xu, M.; Wu, F.; Mo, Y.Y. Negative regulation of lncRNA GAS5 by miR-21. Cell Death Differ. 2013, 20, 1558-1568. [CrossRef] [PubMed]

72. Gao, Y.; Meng, H.; Liu, S.; Hu, J.; Zhang, Y.; Jiao, T.; Liu, Y.; Ou, J.; Wang, D.; Yao, L.; et al. LncRNA-HOST2 regulates cell biological behaviorsin epithelial ovarian cancer through a mechanism involving microRNA let-7b. Hum. Mol. Genet. 2015, 24, 841-852. [CrossRef] [PubMed]

73. Prensner, J.R.; Chen, W.; Han, S.; Iyer, M.K.; Cao, Q.; Kothari, V.; Evans, J.R.; Knudsen, K.E.; Paulsen, M.T.; Ljungman, M.; et al. The long non-coding RNA PCAT-1 promotes prostate cancer cell proliferation through cMyc. Neoplasia 2014, 16, 900-908. [CrossRef] [PubMed]

74. Yoon, J.H.; Abdelmohsen, K.; Srikantan, S.; Yang, X.; Martindale, J.L.; De, S.; Huarte, M.; Zhan, M.; Becker, K.G.; Gorospe, M. LincRNA-p21 suppresses target mRNA. Mol. Cell 2012, 47, 648-655. [CrossRef]

75. Nguyen, T.C.; Cao, X.; Yu, P.; Xiao, S.; Lu, J.; Biase, F.H.; Sridhar, B.; Huang, N.; Zhang, K.; Zhong, S. Mapping RNA-RNA interactome and RNA structure in vivo by MARIO. Nat. Commun. 2016, 7, 12023. [CrossRef]

76. Cao, H.; Wahlestedt, C.; Karranov, P. Strategies to Annotate and Characterize Long Noncoding RNAs: Advantages and Pitfalls. Trends in Genet. 2018, 34, 704-721. [CrossRef]

77. He, J.H.; Han, Z.P.; Zou, M.X.; Wang, L.; Lv, Y.B.; Zhou, J.B.; Cao, M.R.; Li, Y.G. Analyzing the lncRNA, miRNA, and mRNA regulatory network in prostate cancer with bioinformatics software. J. Comput. Biol. 2018, 25, 146-157. [CrossRef]

78. Hafner, M.; Landthaler, M.; Burger, L.; Khorshid, M.; Hausser, J.; Berninger, P.; Rothballer, A.; Ascano, M., Jr.; Jungkamp, A.C.; Munschauer, M.; et al. Transcriptome-wide identification of RNA-binding protein and microRNA target sites by PAR-CLIP. Cell 2010, 141, 129-141. [CrossRef]

79. Li, J.H.; Liu, S.; Zhou, H.; Qu, L.H.; Yang, J.H. starBase v2.0: Decoding miRNA-ceRNA, miRNA-ncRNA and protein-RNA interaction networks from large-scale CLIP-Seq data. Nucleic Acids Res. 2014, 42, D92-D97. [CrossRef] 
80. Tang, J.; Zhuo, H.; Zhang, X.; Jiang, R.; Ji, J.; Deng, L.; Qian, X.; Zhang, F.; Sun, B. A novel biomarker Linc00974 interacting with KRT19 promotes proliferation and metastasis in hepatocellular carcinoma. Cell Death Dis. 2014, 5, e1549. [CrossRef]

81. Kashi, K.; Henderson, L.; Bonetti, A.; Carninci, P. Discovery and functional analysis of lncRNAs: Methodologies to investigate an uncharacterized transcriptome. Biochim. Biophys. Acta 2016, 1859, 3-15. [CrossRef]

82. Kent, O.A.; Mendell, J.T. A small piece in the cancer puzzle: microRNAs as tumor suppressors. Oncogene 2006, 25, 6188-6196. [CrossRef]

83. Lu, J.; Andrew, G.; Clark, A.G. Impact of microRNA regulation on variation in human gene expression. Genome Res. 2012, 22, 1243-1254. [CrossRef]

84. Zhou, K.; Liu, M.; Cao, Y. New insight into microRNA: Functions in cancer: Oncogene-microRNA-tumor suppressor gene network. Front. Mol. Biosci. 2017, 4, 46. [CrossRef]

85. Wang, K.C.; Chang, H.Y. Molecular mechanism of long non-coding RNAs. Mol. Cell 2011, 43, 904-914. [CrossRef]

86. Anastasiadou, E.; Jacob, L.S.; Slack, F.J. Non-coding RNA networks in cancer. Nat. Rev. Cancer 2018, 18, 5-18. [CrossRef]

87. Cai, Y.; Wan, J. Competing endogenous RNA regulations in neurodegenerative disorders: Current challenges and emerging insights. Front. Mol. Neurosci. 2018, 11, 370. [CrossRef]

88. Tao, F.; Tian, X.; Ruan, S.; Shen, M.; Zhang, Z. miR-211 sponges lncRNA MALAT1 to suppress tumor growth and progression through inhibiting PHF19 in ovarian carcinoma. FASEB J. 2018. [CrossRef]

89. Yang, B.; Gao, G.; Wang, Z.; Sun, D.; Wei, X.; Ma, Y.; Ding, Y. Long non-coding RNA HOTTIP promotes prostate cancer cells proliferation and migration by sponging miR-216a-5p. Biosci. Rep. 2018, 38, BSR20180566. [CrossRef]

90. Denzler, R.; Agarwal, V.; Stefano, J.; Bartel, D.P.; Stoffel, M. Assessing the ceRNA hypothesis with quantitative measurements of miRNA and target abundance. Mol. Cell 2014, 54, 766-776. [CrossRef]

91. Thomson, D.W.; Marcel, E.; Dinger, M.E. Endogenous microRNA sponges: Evidence and controversy. Nat. Rev. Genet. 2016, 17, 272-283. [CrossRef] [PubMed]

92. Romero-Barrios, N.; Legascue, M.F.; Benhamed, M.; Federico Ariel, F.; Crespi, M. Splicing regulation by long non-coding RNAs. Nucleic Acids Res. 2018, 46, 2169-2184. [CrossRef] [PubMed]

93. Karapetyan, A.E.; Coen Buiting, C.; Kuiper, R.A.; Marcel, W.; Coolen, M.W. Regulatory roles for long ncRNA and mRNA. Cancers 2013, 5, 462-490. [CrossRef] [PubMed]

94. Tripathi, V.; Ellis, J.D.; Shen, Z.; Song, D.Y.; Pan, Q.; Watt, A.T.; Freier, S.M.; Bennett, C.F.; Sharma, A.; Bubulya, P.A.; et al. The nuclear-retained noncoding RNA MALAT1 regulates alternative splicing by modulating SR splicing factor phosphorylation. Mol. Cell 2010, 39, 925-938. [CrossRef]

95. Salameh, A.; Lee, A.K.; Cardo-Vila, M.; Nunes, D.N.; Efstathiou, E.; Staquicini, F.I.; Dobroff, A.S.; Marchio, S.; Navone, N.M.; Hosoya, H.; et al. PRUNE2 is a human prostate cancer suppressor regulated by the intronic long noncoding RNA PCA3. Proc. Natl. Acad. Sci. USA 2015, 112, 8403-8408. [CrossRef]

96. Cao, L.; Zhang, P.; Li, J.; Wu, M. LAST, a c-Myc-inducible long noncodingRNA, cooperates with CNBP to promote CCND1 mRNA stability in human cells. eLife 2017, 6, e30433. [CrossRef]

97. Faghihi, M.A.; Modarresi, F.; Khalil, A.M.; Wood, D.E.; Sahagan, B.G.; Morgan, T.E.; Finch, C.E.; Laurent, G.S., III; Kenny, P.J.; Wahlestedt, C. Expression of a noncoding RNA is elevated in alzheimer's disease and drives rapid feed-forward regulation of beta-secretase. Nat. Med. 2008, 14, 723-730. [CrossRef]

98. Yoon, J.-H.; Abdelmohsen, K.; Gorospe, M. Post-transcriptional gene regulation by long noncoding RNA. J. Mol. Biol. 2013, 19, 3723-3730. [CrossRef]

99. Tafer, H.; Hofacker, I.L. RNAplex: A fast tool for RNA-RNA interaction search. Bioinformatics 2008, 24, 2657-2663. [CrossRef]

100. Li, J.; Ma, W.; Zeng, P.; Wang, J.; Geng, B.; Yang, J.; Cui, Q. LncTar: A tool for predicting the RNA targets of long noncoding RNAs. Brief. Bioinform. 2015. [CrossRef]

101. Gott, M.J.; Emerson, R.B. Functions and mechanism of RNA editing. Ann. Rev. Genet. 2000, 34, $499-531$. [CrossRef] [PubMed]

102. Szcześniak, M.W.; Makałowska, I. lncRNA-RNA Interactions across the human transcriptome. PLoS ONE 2016, 11, e0150353. [CrossRef] [PubMed] 
103. Quinodoz, S.; Guttman, M. Longnoncoding RNAs: An emerging link between gene regulation and nuclear organization. Cell Chem. Biol. 2014, 24, 652-663.

104. Li, Y.; Syed, J.; Sugiyama, H. RNA-DNA triplex formation by longnoncoding RNAs. Cell Chem. Biol. 2016, 23, 1325-1333. [CrossRef]

105. Shaw, N.N.; Arya, D.P. Recognition of the unique structure of DNA: RNA hybrids. Biochimie 2008, 90, 1026-1039. [CrossRef] [PubMed]

106. Buske, F.A.; Mattick, J.S.; Bailey, T.L. Potential in vivo roles of nucleic acid triple-helices. RNA Biol. 2011, 8 , 427-439. [CrossRef]

107. Bacolla, A.; Wang, G.; Vasquez, K.M. New Perspectives on DNA and RNA Triplexes As Effectors of Biological Activity. PLoS Genet. 2015, 11, e1005696. [CrossRef]

108. Zhou, B.; Li, X.; Luo, D.; Lim, D.H.; Zhou, Y.; Fu, X.D. GRID-seq for comprehensive analysis of global RNA-chromatin interactions. Nat. Protoc. 2019, 14, 2036-2068. [CrossRef]

109. Buske, F.A.; Bauer, D.C.; Mattick, J.S.; Bailey, T.L. Triplex-Inspector: An analysis tool for triplex-mediated targeting of genomic loci. Bioinformatics 2013, 29, 1895-1897. [CrossRef]

110. He, S.; Zhang, H.; Liu, H.; Zhu, H. LongTarget: A tool to predict lncRNA DNA-binding motifs and binding sites via Hoogsteen base-pairing analysis. Bioinformatics 2015, 31, 178-186. [CrossRef]

111. Chu, C.; Qu, K.; Zhong, F.L.; Artandi, S.E.; Chang, H.Y. Genomic maps of long noncoding RNA occupancy reveal principles of RNA-chromatin interactions. Mol. Cell 2011, 44, 667-678. [CrossRef] [PubMed]

112. Vance, K.W.; Ponting, C.P. Transcriptional regulatory functions of nuclear long noncoding RNAs. Trends Genet. 2014, 30, 348-355. [CrossRef]

113. Nagano, T.; Mitchell, J.A.; Sanz, L.A.; Pauler, F.M.; Ferguson-Smith, A.C.; Feil, R.; Fraser, P. The Air noncoding RNA epigenetically silences transcription by targeting G9a to chromatin. Science 2008, 322, 1717-1720. [CrossRef]

114. Grote, P.; Herrmann, B.G. The long non-coding RNA Fendrr links epigenetic control mechanisms to gene regulatory networks in mammalian embryogenesis. RNA Biol. 2013, 10, 1579-1585. [CrossRef] [PubMed]

115. Xu, T.; Huang, M.; Xia, R.; Liu, X.; Sun, M.; Yin, L.; Chen, W.M.; Han, L.; Zhang, E.B.; Kong, R.; et al. Decreased expression of the long non-coding of FENDRR is associated with poor prognosis in gastric cancer and FENDRR regulates gastric cancer cell metastasis by affecting fibronectin1 expression. J. Hematol. Oncol. 2014, 7, 63. [CrossRef] [PubMed]

116. Lin, N.; Chang, K.Y.; Li, Z.; Gates, K.; Rana, Z.A.; Dang, J.; Zhang, D.; Han, T.; Yang, C.S.; Cunningham, T.J.; et al. An evolutionarily conserved long noncoding RNA TUNA controls pluripotency and neural lineage commitment. Mol. Cell 2014, 53, 1005-1019. [CrossRef] [PubMed]

117. Mondal, T.; Subhash, S.; Vaid, R.; Enroth, S.; Uday, S.; Reinius, B.; Mitra, S.; Mohammed, A.; James, A.R.; Hoberg, E.; et al. MEG3 long noncoding RNA regulates the TGF-b pathway genes through formation of RNA-DNA triplex structures. Nat. Commun. 2015, 6, 7743. [CrossRef] [PubMed]

118. O’Leary, V.B.; Ovsepian, S.V.; Carrascosa, L.G.; Buske, F.A.; Radulovic, V.; Niyazi, M.; Moertl, S.; Trau, M.; Atkinson, M.J.; Anastasov, N. PARTICLE, a triplex-forming long ncRNA, regulates locus-specific methylation in response to low-dose irradiation. Cell Rep. 2015, 11, 474-485. [CrossRef]

119. West, J.A.; Davis, C.P.; Sunwoo, H.; Simon, M.D.; Sadreyev, R.I.; Wang, P.I.; Tolstorukov, M.Y.; Kingston, R.E. The long noncoding RNAs NEAT1 and MALAT1 bind active chromatin sites. Mol. Cell 2014, 55, 791-802. [CrossRef]

120. Bond, C.S.; Fox, A.H. Paraspeckles: Nuclear bodies built on long noncoding RNA. J. Cell. Biol. 2009, 186, 637-644. [CrossRef]

121. Martianov, I.; Ramadass, A.; Barros, A.; Chow, N.; Akoulitchev, A. Repression of the human dihydrofolate reductase gene by a non-coding interfering transcript. Nature 2007, 445, 666-670. [CrossRef] [PubMed]

122. Blume, S.W.; Meng, Z.; Shrestha, K.; Snyder, R.C.; Emanuel, P.D. The 5'-untranslated RNA of the human dhfr minor transcript alters transcription pre-initiation complex assembly at the major (core) promoter. J. Cell. Biochem. 2003, 88, 165-180. [CrossRef] [PubMed]

123. Deng, Z.; Norseen, J.; Wiedmer, A.; Riethman, H.; Lieberman, P.M. TERRA RNA binding to TRF2 facilitates heterochromatin formation and ORC recruitment at telomeres. Mol. Cell. 2009, 35, 403-413. [CrossRef] [PubMed]

124. Xu, Y.; Kimura, T.; Komiyama, M. Human telomere RNA and DNA form an intermolecular G-quadruplex. Nucleic Acids Symp. Ser. 2008, 52, 169-170. [CrossRef] 
125. Toubiana, S.; Selig, S. DNA: RNA hybrids at telomeres-when it is better to be out of the R loop. FEBS J. 2018, 285, 2552-2566. [CrossRef]

126. Xu, Y.; Suzuki, Y.; Ito, K.; Komiyama, M. Telomeric repeat-containing RNA structure in living cells. Proc. Natl. Acad. Sci. USA 2010, 107, 14579-14584. [CrossRef]

127. Postepska-Igielska, A.; Giwojna, A.; Gasri-Plotnitsky, L.; Schmitt, N.; Dold, A.; Ginsberg, D.; Grummt, I. LncRNA Khps1 Regulates Expression of the proto-oncogene SPHK1 via triplex-mediated changes in chromatin structure. Mol. Cell 2015, 60, 626-636. [CrossRef]

128. Yang, Y.; Wen, L.; Zhu, H. Unveiling the hidden function of long non-coding RNA by identifying its major partner-protein. Cell Biosci. 2015, 5, 59. [CrossRef]

129. Sun, X.; Haider Ali, M.S.S.; Moran, M. The role of interactions of long non-coding RNAs and heterogeneous nuclear ribonucleoproteins in regulating cellular functions. Biochem. J. 2017, 474, 2925-2935. [CrossRef]

130. Wang, K.C.; Chang, H.Y. Molecular mechanisms of longnoncoding RNAs. Mol. Cell 2011, 43, $904-914$. [CrossRef]

131. Barra, J.; Leucci, E. Probing long non-coding RNA-protein interactions. Front. Mol. Biosci. 2017, 4, 45. [CrossRef]

132. Hellman, L.M.; Fried, M.G. Electrophoretic mobility shift assay (EMSA) for detecting protein-nucleic acid interactions. Nat. Protoc. 2007, 2, 1849-1861. [CrossRef] [PubMed]

133. Lin, R.J. RNA protein interaction protocols. Methods Mol. Biol. 2008, 488, 5-7.

134. Konig, J.; Zarnack, K.; Luscombe, N.M.; Ule, J. Protein-RNA interactions: New genomic technologies and perspectives. Nat. Rev. Genet. 2011, 13, 77-83. [CrossRef]

135. Barnes, C.; Kanhere, A. Identification of RNA-protein interactions through in vitro RNA pull-down assays. Methods Mol. Biol. 2016, 1480, 99-113. [PubMed]

136. Zheng, X.; Cho, S.; Moon, H.; Loh, T.J.; Jang, H.N.; Shen, H. Detecting RNA-protein interaction using end-labeled biotinylated RNA oligonucleotides and immunoblotting. Methods Mol. Biol. 2016, 1421, $35-44$. [PubMed]

137. Jalali, S.; Gandhi, S.; Scaria, V.S. Distinct and modular organization of protein interacting sites in long non-coding RNAs. Front. Mol. Biosci. 2018, 5, 27. [CrossRef]

138. Yoon, J.H.; Gorospe, M. Cross-Linking Immunoprecipitation and qPCR (CLIP-qPCR) Analysis to map interactions between longnoncoding RNAs and RNA-binding proteins. Methods Mol. Biol. 2016, 1402, 11-17.

139. Garzia, A.; Meyer, C.; Morozov, P.; Sajek, M.; Tuschl, T. Optimization of PAR-CLIP for transcriptome-wide identification of binding sites of RNA-binding proteins. Methods 2017, 118-119, 24-40. [CrossRef]

140. Kiefer, L.; Schofield, J.A.; Simon, M.D. Expanding the nucleoside recoding toolkit: Revealing RNA population dynamics with 6-thioguanosine. J. Am. Chem. Soc. 2018, 140, 14567-14570. [CrossRef]

141. Quek, X.C.; Thomson, D.W.; Maag, J.L.; Bartonicek, N.; Signal, B.; Clark, M.B.; Gloss, B.S.; Dinger, M.E. lncRNAdb v2.0: Expanding the reference database for functional long noncoding RNAs. Nucleic Acids Res. 2015, 43, D168-D173. [CrossRef] [PubMed]

142. Volders, P.J.; Anckaert, J.; Verheggen, K.; Nuytens, J.; Martens, L.; Mestdagh, P.; Vandesompele, J. LNCipedia 5: Towards a reference set of human long non-coding RNAs. Nucleic Acids Res. 2019, 47, D135-D139. [CrossRef] [PubMed]

143. Frankish, A.; Diekhans, M.; Ferreira, A.M.; Johnson, R.; Jungreis, I.; Loveland, J.; Mudge, J.M.; Sisu, C.; Wright, J.; Armstrong, J.; et al. GENCODE reference annotation for the human and mouse genomes. Nucleic Acids Res. 2019, 47, D766-D773. [CrossRef] [PubMed]

144. Ribeiro, D.M.; Zanzoni, A.; Cipriano, A.; Delli Ponti, R.; Spinelli, L.; Ballarino, M.; Bozzoni, I.; Tartaglia, G.G.; Brun, C. Protein complex scaffolding predicted as a prevalent function of long non-codingRNAs. Nucleic Acids Res. 2018, 46, 917-928. [CrossRef]

145. Gupta, R.A.; Shah, N.; Wang, K.C.; Kim, J.; Horlings, H.M.; Wong, D.J.; Tsai, M.C.; Hung, T.; Argani, P.; Rinn, J.L.; et al. Long non-coding RNA HOTAIR reprograms chromatin state to promote cancer metastasis. Nature 2010, 464, 1071-1076. [CrossRef]

146. Schorderet, P.; Duboule, D. Structural and functional differences in the long non-coding RNA hotair in mouse and human. PLoS Genet. 2011, 7, e1002071. [CrossRef]

147. Kogo, R.; Shimamura, T.; Mimori, K.; Kawahara, K.; Imoto, S.; Sudo, T.; Tanaka, F.; Shibata, K.; Suzuki, A.; Komune, S.; et al. Long noncoding RNA HOTAIR regulates polycomb-dependent chromatin modification and is associated with poor prognosis in colorectal cancers. Cancer Res. 2011, 71, 6320-6326. [CrossRef] 
148. Wang, P.; Xue, Y.; Han, Y.; Lin, L.; Wu, C.; Xu, S.; Jiang, Z.; Xu, J.; Liu, Q.; Cao, X. The STAT3-binding long noncoding RNA lnc-DC controls human dendritic cell differentiation. Science 2014, 344, 310-313. [CrossRef]

149. Pandey, R.R.; Mondal, T.; Mohammad, F.; Enroth, S.; Redrup, L.; Komorowski, J.; Nagano, T.; Mancini-Dinardo, D.; Kanduri, C. Kcnq1ot1 antisense noncoding RNA mediates lineage-specific transcriptional silencing through chromatin-level regulation. Mol. Cell 2008, 32, 232-246. [CrossRef]

150. Kanduri, C. Kcnq1ot1: A chromatin regulatory RNA. Semin. Cell. Dev. Biol. 2011, 22, 343-350. [CrossRef]

151. Schoeftner, S.; Sengupta, A.K.; Kubicek, S.; Mechtler, K.; Spahn, L.; Koseki, H.; Jenuwein, T.; Wutz, A. Recruitment of PRC1 function at the initiation of $\mathrm{X}$ inactivation independent of PRC2 and silencing. EMBO J. 2006, 25, 3110-3122. [CrossRef] [PubMed]

152. Moindrot, B.; Brockdorff, N. RNA binding proteins implicated in Xist-mediated chromosome silencing. Semin. Cell Dev. Biol. 2016, 56, 58-70. [CrossRef] [PubMed]

153. Seidl, C.I.; Stricker, S.H.; Barlow, D.P. The imprinted Air ncRNA is an atypical RNAPII transcript that evades splicing and escapes nuclear export. EMBO J. 2006, 25, 3565-3575. [CrossRef] [PubMed]

154. Santoro, F.; Mayer, D.; Klement, R.M.; Warczok, K.E.; Stukalov, A.; Barlow, D.P.; Pauler, F.M. Airn transcriptional overlap, but not its lncRNA products, induces imprinted Igf2r silencing. Development 2013, 140, 1184-1195. [CrossRef] [PubMed]

155. Yap, K.L.; Li, S.; Muñoz-Cabello, A.M.; Raguz, S.; Zeng, L.; Mujtaba, S.; Gil, J.; Walsh, M.J.; Zhou, M.M. Molecular interplay of the noncoding RNA ANRIL and methylated histone H3 lysine 27 by polycomb CBX7 in transcriptional silencing of INK4a. Mol. Cell 2010, 38, 662-674. [CrossRef] [PubMed]

156. Lian, Y.; Cai, Z.; Gong, H.; Xue, S.; Wu, D.; Wang, K. HOTTIP: A critical oncogenic long non-coding RNA in human cancers. Mol. Biosyst. 2016, 12, 3247-3253. [CrossRef]

157. Runge, S.; Nielsen, F.C.; Nielsen, J.; Lykke-Andersen, J.; Wewer, U.M.; Christiansen, J. H19 RNA binds four molecules of insulin-like growth factor II mRNA-binding protein. J. Biol. Chem. 2000, 275, 29562-29569. [CrossRef]

158. Jiang, W.; Liu, Y.; Liu, R.; Zhang, K.; Zhang, Y. The lncRNA DEANR1 facilitates human endoderm differentiation by activating FOXA2 expression. Cell Rep. 2015, 11, 137-148. [CrossRef]

159. Dimitrova, N.; Zamudio, J.R.; Jong, R.M.; Soukup, D.; Resnick, R.; Sarma, K.; Ward, A.J.; Raj, A.; Lee, J.T.; Sharp, P.A.; et al. LincRNA-p21 activates p21 in cis to promote Polycomb target gene expression and to enforce the G1/S checkpoint. Mol. Cell 2014, 54, 777-790. [CrossRef]

160. Huarte, M.; Guttman, M.; Feldser, D.; Garber, M.; Koziol, M.J.; Kenzelmann-Broz, D.; Khalil, A.M.; Zuk, O.; Amit, I.; Rabani, M.; et al. A large intergenic noncoding RNA induced by p53 mediates global gene repression in the p53 response. Cell 2010, 142, 409-419. [CrossRef]

161. Puvvula, P.K.; Desetty, R.D.; Pineau, P.; Marchio, A.; Moon, A.; Dejean, A.; Bischof, O. Long noncoding RNA PANDA and scaffold-attachment-factor SAFA control senescence entry and exit. Nat. Commun. 2014, 5, 5323. [CrossRef] [PubMed]

162. Hung, T.; Wang, Y.; Lin, M.F.; Koegel, A.K.; Kotake, Y.; Grant, G.D.; Horlings, H.M.; Shah, N.; Umbricht, C.; Wang, P.; et al. Extensive and coordinatedtranscription of noncoding RNAs within cell-cycle promoters. Nat. Genet. 2011, 43, 621-629. [CrossRef] [PubMed]

163. Kino, T.; Hurt, D.E.; Ichijo, T.; Nader, N.; Chrousos, G.P. Noncoding RNA gas5 is a growth arrest- and starvation-associated repressor of the glucocorticoid receptor. Sci. Signal. 2010, 3, ra8. [CrossRef] [PubMed]

164. Yang, Z.; Zhu, B.Q.; Luo, B.K.; Zhou, Q. The 7SK small nuclear RNA inhibits the CDK9/cyclin T1 kinase to control transcription. Nature 2001, 414, 317-322. [CrossRef]

165. Barboric, M.; Lenasi, T.; Chen, H.; Johansen, E.B.; Guo, S.; Peterlin, B.M. 7SK snRNP/P-TEFb couples transcription elongation with alternative splicing and is essential for vertebrate development. Proc. Natl. Acad. Sci. USA 2009, 106, 7798-7803. [CrossRef]

166. Tsuiji, H.; Yoshimoto, R.; Hasegawa, Y.; Furuno, M.; Yoshida, M.; Nakagawa, S. Competition between a noncoding exon and introns: Gomafu contains tandem UACUAAC repeats and associates with splicing factor-1. Genes Cells 2011, 16, 479-490. [CrossRef]

167. Yoshimoto, R.; Mayeda, A.; Yoshida, M.; Nakagawa, S. MALAT1 long non-coding RNA in cancer. Biochim. Biophys. Acta 2016, 1859, 192-199. [CrossRef]

168. Ramos, A.D.; Andersen, R.E.; Liu, S.J.; Lim, D.A. The long noncoding RNA Pnky regulates neuronal differentiation of embryonic and postnatal neural stem cells. Cell Stem Cell 2015 16, 439-447. [CrossRef] 
169. Antoniou, D.; Stergiopoulos, A.; Politis, P.K. Recent advances in the involvement of long non-coding RNAs in neural stem cell biology and brain pathophysiology. Front. Physiol. 2014, 5, 155. [CrossRef]

170. Cho, K.O.; Hsieh, J. The lncRNA Pnky in the brain. Cell Stem Cell 2015, 16, 344-345. [CrossRef]

171. Wang, H.; Iacoangeli, A.; Lin, D.; Williams, K.; Denman, R.B.; Hellen, C.U.; Tiedge, H. Dendritic BC1 RNA in translational control mechanisms. J. Cell. Biol. 2005, 171, 811-821. [CrossRef] [PubMed]

172. Li, Z.; Chao, T.C.; Chang, K.Y.; Lin, N.; Patil, V.S.; Shimizu, C.; Head, S.R.; Burns, J.C.; Rana, T.M. Thelong noncoding RNATHRIL regulates TNF $\alpha$ expression through its interaction with hnRNPL. Proc. Natl. Acad. Sci. USA 2014, 111, 1002-1007. [CrossRef]

173. Davidovich, C.; Cech, T. The recruitment of chromatin modifiers by long noncoding RNAs: Lessons from PRC2. RNA 2015, 1, 2007-2022. [CrossRef] [PubMed]

174. Angrand, P.O.; Vennin, C.; Le Bourhis, X.; Adriaenssens, E. The role of long non-coding RNAs in genome formatting and expression. Front. Genet. 2015, 6, 165. [CrossRef] [PubMed]

175. Chittock, E.C.; Latwiel, S.; Miller, T.C.; Müller, C.W. Molecular architecture of polycomb repressive complexes. Biochem. Soc. Trans. 2017, 45, 193-205. [CrossRef] [PubMed]

176. Li, J.; Chen, Y.; Xu, X.; Jones, J.; Tiwari, M.; Ling, J.; Ling, J.; Wang, Y.; Harismedy, O.; Sen, G.L. HNRNPK maintains epidermal progenitor function through transcription of proliferation genes and degrading differentiation promoting mRNAs. Nat. Commun. 2019, 10, 1-14. [CrossRef]

177. McHugh, C.A.; Russell, P.; Guttman, M. Methods for comprehensive experimental identification of RNA-protein interactions. Genome Biol. 2014, 15, 203. [CrossRef]

178. Liu, A.; Liu, S. Non-coding RNAs in cancer biology. In Advances in Experimental Medicine and Biology; Son, E., Ed.; Springer: Berlin/Heidelberg, Germany, 2016; Volume 927, pp. 367-389.

179. Zhu, S.; Wang, J.; He, Y.; Meng, N.; Yan, G.R. Peptides/Proteins encoded by non-coding RNA: A novel resource bank for drug targets and biomarkers. Front. Pharmacol. 2018, 9, 1295. [CrossRef]

180. Chugunova, A.; Navalayeu, T.; Dontsova, O.; Sergiev, P. Mining for small translated ORFs. J. Proteome Res. 2018, 17, 1-11. [CrossRef]

181. Matsumoto, A.; Nakayama, K.I. Hidden peptides encoded by putative noncoding RNAs. Cell Struct. Funct. 2018, 43, 75-83. [CrossRef] [PubMed]

182. Ruiz-Orera, J.; Verdaguer-Grau, P.; Villanueva-Canas, J.L.; Messegue, X.; Alba, M.M. Functional and non-functional classes of peptides produced by long non-coding RNAs. biorXiv 2016. [CrossRef]

183. Choi, S.W.; Kim, H.W.; Nam, J.W. The small peptide world in long noncoding RNAs. Brief. Bioinform. 2018. [CrossRef] [PubMed]

184. Chong, S. Overview of cell-free protein synthesis: Historic landmarks, commercial systems, and expanding applications. Curr. Protoc. Mol. Biol. 2014, 108, 1-11. [CrossRef] [PubMed]

185. Guthals, A.; Bandeira, N. Peptide identification by tandem mass spectrometry with alternate fragmentation modes. Mol. Cell. Proteomics 2012, 11, 550-557. [CrossRef] [PubMed]

186. Ingolia, N.T. Ribosome profiling: New views of translation, from single codons to genome scale. Nat. Rev. Genet. 2014, 15, 205-213. [CrossRef]

187. Nam, J.W.; Choi, S.W.; You, B.H. Incredible RNA: Dual functions of coding and noncoding. Mol. Cells 2016, 39, 367-374.

188. Anderson, D.M.; Anderson, K.M.; Chang, C.L.; Makarewich, C.A.; Nelson, B.R.; McAnally, J.R.; Kasaragod, P.; Shelton, J.M.; Liou, J.; Bassel-Duby, R.; et al. A micropeptide encoded by a putative long noncoding RNA regulates muscle performance. Cell 2015, 160, 595-606. [CrossRef]

189. Matsumoto, A.; Pasut, A.; Matsumoto, M.; Yamashita, R.; Fung, J.; Monteleone, E.; Saghatelian, A.; Nakayama, K.I.; Clohessy, J.G.; Pandolfi, P.P. mTORC1 and muscle regeneration are regulated by the LINC00961-encoded SPAR polypeptide. Nature 2017, 541, 228-232. [CrossRef]

190. Nelson, B.R.; Makarewich, C.A.; Anderson, D.M.; Winders, B.R.; Troupes, C.D.; Wu, F.; Reese, A.L.; McAnally, J.R.; Chen, X.; Kavalali, E.T.; et al. A peptide encoded by a transcript annotated as long noncoding RNA enhances SERCA activity in muscle. Science 2016, 351, 271-275. [CrossRef]

191. Huang, J.Z.; Chen, M.; Gao, X.C.; Zhu, S.; Huang, H.; Hu, M.; Zhu, H.; Yan, G.R. A peptide encoded by a putative lncRNA HOXB-AS3 suppresses colon cancer growth. Mol. Cell 2017, 68, 171-184. [CrossRef]

192. Gestelanf, R.F.; Cech, T.R.; Atkins, J.F. (Eds.) The RNA World, 3rd ed.; Cold Spring Harbor Laboratory Press: New York, NY, USA, 2005. 
193. Warner, K.D.; Hajdin, C.E.; Weeks, K.M. Principles for targeting RNA with drug-like small molecules. Nat. Rev. Drug Discov. 2018, 17, 547-558. [CrossRef] [PubMed]

194. Brown, J.A.; Bulkley, D.; Wang, J.; Valenstein, M.L.; Yario, T.A.; Steitz, T.A.; Steitz, J.A. Structural insights into the stabilization of MALAT1 noncoding RNA by a bipartite triple helix. Nat. Struct. Mol. Biol. 2014, 21, 633-640. [CrossRef] [PubMed]

195. Brown, J.A.; Kinzig, C.G.; DeGregorio, S.J.; Steitz, J.A. Hoogsteen-position pyrimidines promote the stability and function of the MALAT1 RNA triple helix. RNA 2016, 22, 743-749. [CrossRef]

196. Brown, J.A.; Kinzig, C.G.; DeGregorio, S.J.; Steitz, J.A. Methyltransferase-like protein 16 binds the 3'-terminal triple helix of MALAT1 long noncoding RNA. Proc. Nat. Acad. Sci. USA 2016, 113, 14013-14018. [CrossRef]

197. Donlic, A.; Hargrove, A.E. Targeting RNA in mammalian systems with small molecules. Wiley Interdiscip. Rev. RNA 2018, 9, e1477. [CrossRef] [PubMed]

198. Liu, F.; Somarowthu, S.; Pyle, A.M. Visualizing the secondary and tertiary architectural domains of lncRNA RepA. Nat. Chem. Biol. 2017, 13, 282-289. [CrossRef] [PubMed]

199. Smola, M.J.; Christy, T.W.; Inoue, K.; Nicholson, C.O.; Friedersdorf, M.; Keene, J.D.; Lee, D.M.; Calabrese, J.M.; Weeks, K.M. SHAPE reveals transcript-wide interactions, complex structural domains, and protein interactions across the Xist lncRNA in living cells. Proc. Natl. Acad. Sci. USA 2016, 113, 10322-10327. [CrossRef]

200. Owens, M.C.; Clark, S.C.; Yankey, A.; Somarowthu, S. Identifying structural domains and conserved regions in the long non-coding RNA lncTCF7. Int. J. Mol. Sci. 2019, 20, 4770. [CrossRef]

201. Fatemi, R.P.; Salah-Uddin, S.; Modarresi, F.; Khoury, N.; Wahlestedt, C.; Faghihi, M.A. Screening for small-molecule modulators of long noncoding RNA-protein Interactions using AlphaScreen. J. Biomol. Screen. 2015, 20, 1132-1141. [CrossRef]

202. Zhang, Y.; Zeng, D.; Cao, J.; Wang, M.; Shu, B.; Kuang, G.; Qu, T.M.; Tan, G.H.; Gu, L.Q.; Huang, Z.S.; et al. Interaction of quindoline derivative withtelomeric repeat-containing RNA induces telomeric DNA-damage response in cancer cells through inhibition of telomeric repeat factor 2. Biochim. Biophys. Acta 2017, 1861, 3246-3256. [CrossRef] [PubMed]

203. Shi, Y.; Parag, S.; Patel, R.; Lui, A.; Murr, M.; Cai, J.; Patel, N.A. Stabilization of lncRNA GAS5 by a small molecule and its implications in diabetic. Cell Chem. Biol. 2019, 26, 319-330. [CrossRef] [PubMed]

204. Bowden, R.; Davies, R.W.; Heger, A.; Pugnamenta, A.T.; de Cesare, M.; Oikonen, L.E.; Parkes, D.; Freeman, C.; Dhalla, F.; Patel, S.Y. Sequencing of human genomes with nanopore technology. Nat. Commun. 2019, 10, 1869. [CrossRef] [PubMed]

205. Makałowski, W.; Shabardina, V.J. Bioinformatics of nanopore sequencing. Hum. Genet. 2020, 65, 61-67. [CrossRef]

206. Gupta, D.; Bhattacharjee, O.; Mandal, D.; Sen, M.K.; Dey, D.; Dasgupta, A.; Kazi, T.A.; Gupta, R.; Sinharoy, S.; Acharya, K. CRISPR-Cas9 system: A new-fangled dawn in gene editing. Life Sci. 2019, 23, 116636. [CrossRef]

207. Ali, Z.; Mahas, A.; Mahfouz, M. CRISPR/Cas13 as a tool for RNA interference. Trends Plant. Sci. 2018, 23, 374-378. [CrossRef]

(C) 2020 by the authors. Licensee MDPI, Basel, Switzerland. This article is an open access article distributed under the terms and conditions of the Creative Commons Attribution (CC BY) license (http://creativecommons.org/licenses/by/4.0/). 